Historic, Archive Document

Do not assume content reflects current scientific knowledge, policies, or practices. 



\subsection{1}

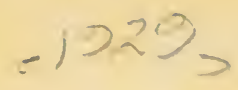

UIRPXFY RFClextron + JAN 17 193i *

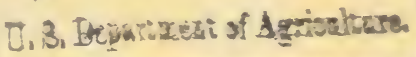

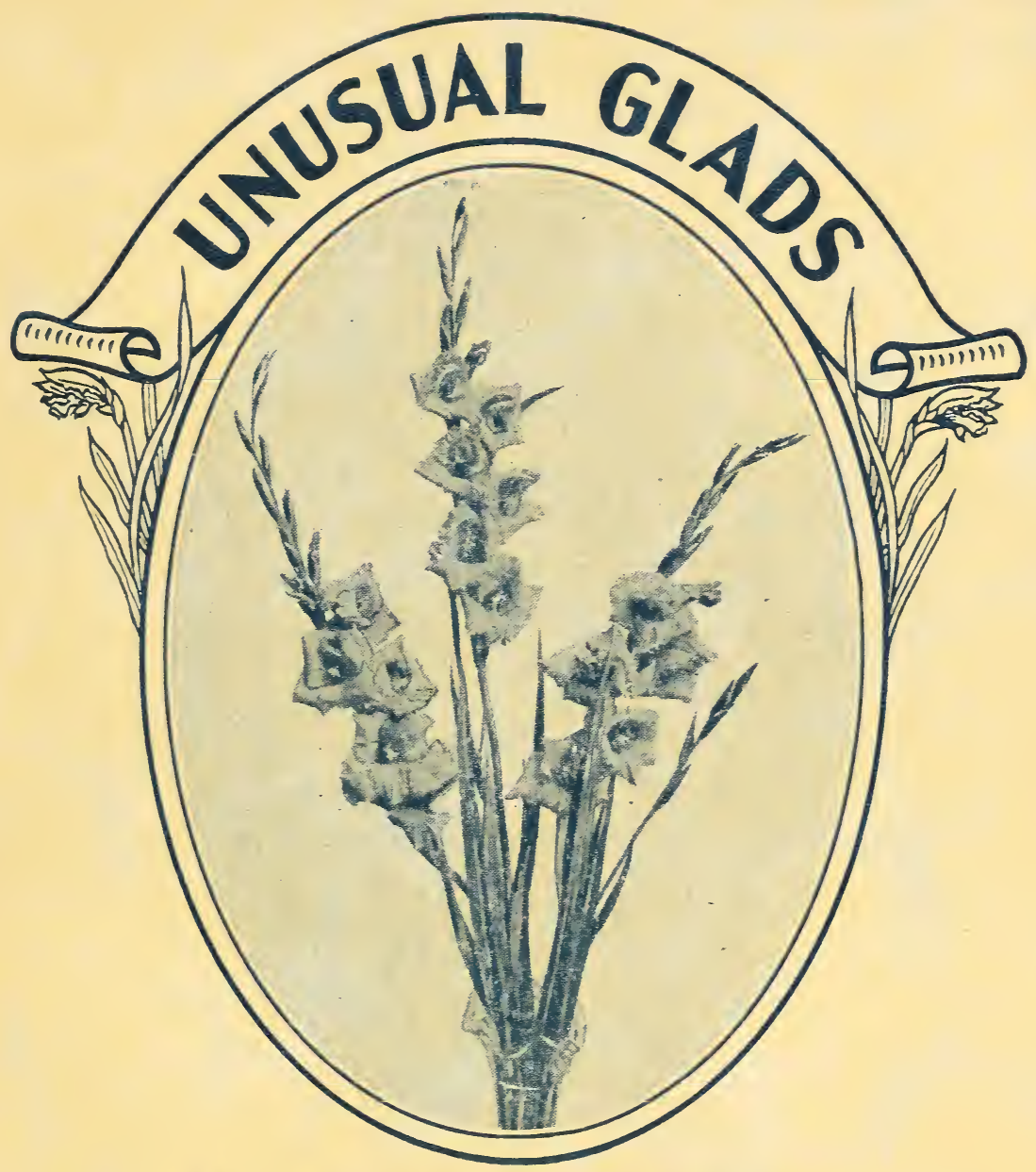

G. W. THACKER

ROCKFORD, MICH. 


\section{On The Other Side}

We go our ways in life too much alone;

We hold ourselves too far from all our kind;

Too often we are dead to sigh and moan;

Too often to the weak and helpless blind;

Too often, where distress and want abide,

We turn and pass upon the other side.

The other side is trodden smooth and worn

By footsteps passing idly all the day.

Where lie the bruised ones that faint and mourn,

Is seldom more than an untrodden way;

Our selfish hearts are for our feet the guide,

They lead us by upon the other side.

It should be ours the oil and wine to pour

Into the bleeding wounds of stricken ones;

To take the smitten and the sick and sore,

And bear them where a stream of blessing runs;

Instead, we look about-the way is wide,

And so we pass upon the other side.

Oh, friends and brothers, gliding down the years,

Humanity is calling each and all

In tender accents born of grief and tears!

I pray you listen to the thrilling call;

You cannot, in your cold and selfish pride,

Pass guiltlessly by on the other side!

-Coates Kinney. 


\section{Greetings}

This, our fifth anniversary catalog comes to you from our new location. Here we expect to give more undivided attention to our glads, and expect to continue a high grade collection-perhaps the finest in the country-ever searching the world for new worth while varieties. And here we hope-we plan-and buildto greater success in our chosen ine.

May we express our appreciation of not only the orders, bus the kind words expressed by so many friends throughout the world, upon the efforts put forth in getting out a catalog which we hope to be worth while; at our efforts in sending satisfaction with theorders; and most of all, the appreciation of $\mathrm{th}$ e friendships which have been builded upon common interest in this wonderful flower throughout the past years-and which

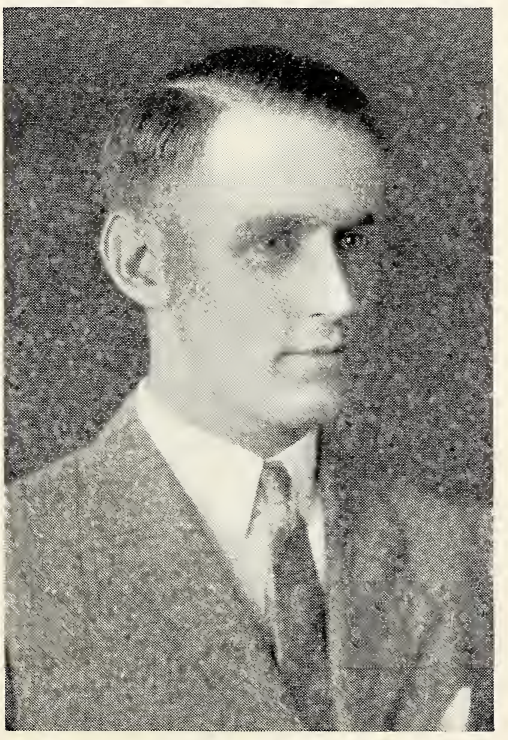

HAROLD CURTIS

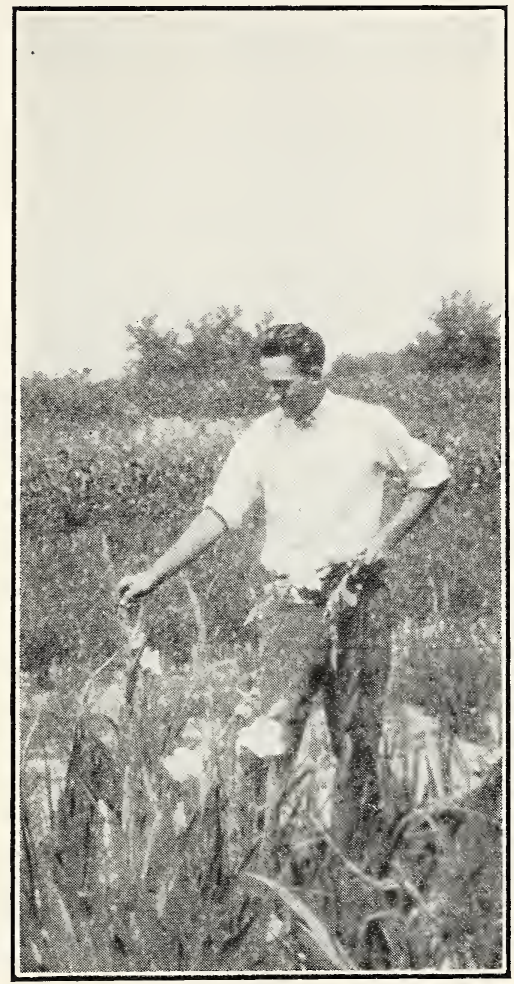

G. W. THACKER

are of infinitely greater worth than any material success.

And here is the other half of "we"-who is helping the year around seeing that your orders are out at the proper time during the shipping season, and that growing continues properly during the summer. And besides -if you are interested in dahlias -write him. He is bringing together a fine collection of "Unusual Dahlias" and can already supply many of the better varieties. Do you wonder that "we" hope for great things in the future? 


\section{GUARANTEE- \\ "We Guarantee Satisfaction"}

This holds true in quality, size and trueness of the bulbs. And in the price you pay. As early as this, it is impossible to place the price as accurately as we should like. We shall meet those of the originator should they be lowered, and of any reliable grower, in extra bulbs. Always we insist that you get good value for your money. Do not hesitate to send orders because of the price.

\section{EXTRAS}

As our list of prices this season is both retail and wholesale, we do not offer a certain per cent of extras, but on retail orders, we should appreciate it if you would give us a list of the varieties you would like as extras, and we shall endeavor to do our best with it.

\section{AWARDS-}

Our exhibits this season were much more limited than last, because of a late planting. However, at Springfield, we received nine ribbons, including collections of foreign and domestic varieties. And at East Lansing, about fifteen awards, including medal for second best collection, and medal for best display of primulinus. This is the second consecutive year for this award.

\section{QUALITY -}

It is generally conceded that Northern grown glads are superior in vigor

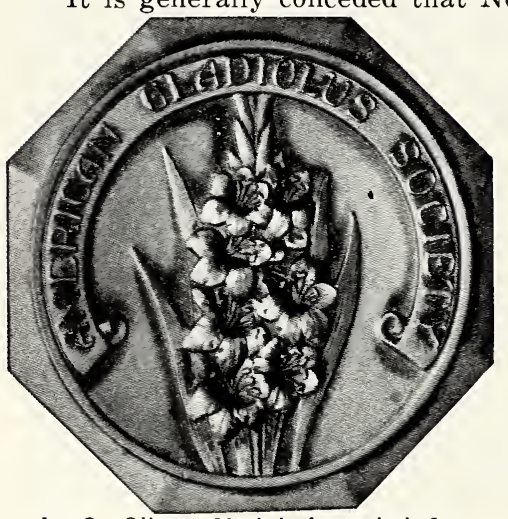

A. G. Silver Medal Awarded for Finest Collection, Toledo, 1928 and hardiness to those grown in other localities. And just as Michigan potatoes are sought after for seed throughout the country, so has Michigan because of her fine conditions, become the largest producer of gladiolus bulbs of any state in the Union.

We believe we have as fine a list of glads as can be found in the country. And every variety is our own growing, treated with a mercuric compound before panting, grown dry, and cured carefully, all preventatives of possible disease. We do not list a variety and then buy stock promiscuously throughout the country to fill orders. With this combination of clean buibs of splendid varieties, at prices as low as any-we leave you to be the judge. The verdict?

\section{DESCRIPTIONS AND DATA}

May we say in explanation that quite a number of the varieties were bloomed from small buibs, and that the blooming season was quite dry. Many varieties were not up to their usual form, and the size and height were impaired. Thus, the data given is but comparative, and must be taken thus. Please do not hold us responsible for anything said herein, but it is as the varieties showed this season.

\section{GROUPINGS}

Please tell us how you like the idea we are using this season in grouping the varieties and note the index on the price sheet. Would you prefer the prices listed in the main body of the catalog?

We feel that perhaps you may wish to keep the catalog for reference and that the prices will of course be of no interest after this winter. In any event, we wel-

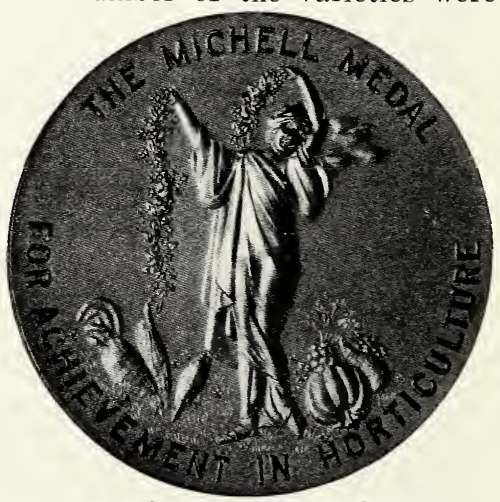

Mitchell Medal for Finest Display Primulinus, East Lansing, 1928 come suggestions as to the betterment of our catalog from year to year. 


\section{The Finest of Them!}

The past season we grew, from the corners of the earth, a great many varieties, - and they varied greatly in quality. Some of the better things we list herewith, stating the defects as well as the outstanding features.

May, however, these comments be taken for what they are worth-the opinion of but one grower-or at the most, two or three, and under one locality. Too, growing conditions were abnormal-the drought being excessive throughout the blooming season.

\section{YELLOWS}

The first yellow that bloomed the past season was about the first variety to bloom-Chas. D. Thomas. This glad should become extremely popular because it is the finest early yellow we have seen. The fine clear soft color, slightly tinted pink, is of the finest form and spike. Don't miss this one. Golden Glow is a nice improved Golden Measure. It is tall like that old rariety and slightly deeper in color. The Grand Guardian is of fine color, with slight throat markings. If a fault-we would like a few more florets on a spike. The growth is vigorous however and it is a good propagator. Tobersun seemed to resemble the variety in throat markings, neither being very distinct, but seems to be later. We thought Lovalty very fine this season. The deep color and fine spikes with the wonderful growth makes it very worthy. With us, germination was not of the best but this fault may be but local. Borrowed Gold did not make a very tall spike, but this may have been due to the excessive drought. Canberra is a very good variety of the Golden Measure type. We should hesitate howerer to call it the finest yellow. Ruffled Gold, while older, still looks very good, but did not show up quite so good color as it has in other vears. The form, however, is most attractive. Lily of Gold is of exquisite color and is so ruffled and frilled that it appears almost fringed. Growth however, does not seem to be all that could be desired. Antione is a grand deep color on a good spike,-sometimes curved-and good sized ruffled flowers. It is among the foremost. Mongolia seems to have more prim blood, but is of the same deep color and perhaps somewhat better habits. It looks splendid commercially, as does Antione. Shasta Gold is a good slender yellow. It is lighter than the former howerer. Cleopatra is perhaps the finest bronze yellow. It is a large heary flower and growth is very vigorous, but in so many localities does not propagate. Lady Esther is a fine grower and large flower, but more of a cream than a vellow. Yellow Perfection is a fine soft color with several florets open. A fine propagator. Two of the finest yellows I have left until the last and these are Primate and Heliosa. The former should make a great commercial variety, for it combines excellent color, tall slender spike, good size, and while some prim blood makes it slightly hooded, it also gives it wonderful propagating qualities so it should soon be within reach. Heliosa, on the other hand is pre-eminently an exhibition flower. The color is deep and pure, florets large and wide open, and of the finest form I know, in a yellow. The petals are fluted, and ruffled until the flower appears lacinated. Spikes are good height and the variety was in bloom all season. They may appear cur'ved however, and it is a very poor propagator.

\section{BLUE}

Yes, we grew Blue Triumphator and liked it. Everyone was a bit disappointed in the color, for it is quite similar to Heavenly blue tho a bit more lavender-certainly no deeper. But the grand spike of six inch bloom certainly leares nothing to be desired. After this one, there are several blues which are about equal in value. Ara Maria and Gertrude Pfitzer, while not particularly similar, are about as nearly blue as any. I like the former tho the color has a peculiar shade to it and almost a red throat blotch. But the spike and florets are of fine form, and it is much to be desired. The latter is similar to the old Badenia in color, but a fine grower, and much to be desired rarietr. Faith is similar to Heavenly Blue in color, but does not fade when opened indoor. Both varieties are light. The former is the best propagator of any blue we have found, but the foliage is not as good as others. Blue Boy is about as near to real sky blue as anything we have seen. It is not so attractive as some others, but in color, is almost there. An Australian variety, 
Olivar, was considered by the judges at Springfield this season to be nearer blue than any others. It is early too, but sometimes crooks. Daintiness is a nice lavender blue-heavily blotched. It attracts much attention. Mrs. Konynenburg and Geraldine Farrar continue to hold their own among the older varieties. We had the finest spikes of the latter the past season that we have ever grown.

\section{LAVENDER}

After all is said and done, there is no better deep lavender than Minuetso far as flower is concerned. It is among the most difficult varieties to germinate, but the flower is the measure by which all others are judged. Chief among its features is the utter lack of streaking in any weather. Dr. Moody, on the other hand, is somewhat apt to show deeper color, but the immense florets on splendid spikes makes it of much value commercially in spite of this, particularly since it is one of the strongest propagators we have, and because it is quite early. Then there are the lighter lavenders with the clear throats. The leaders among these are Berty Snow, Miss Des Moines, and Jane Adams. The former, to my mind, is the most beautiful and I believe, the best propagator, but all do not bear me up on this. Miss Des Moines however, like Minuet, never streaks, and thus has a place among the very foremost. Jane Adams is somewhat larger than the others, but does not open so many florets and has a shorter spike. Berty Snow is a grand all around variety, and this thira season's trial has not changed our opinion of it in the least, for never, with us, has it come streaked. Then we have Bright Wings, a huge orchid shaped lavender, early and grand. This is one of the outstanding new glads. Amethyst is a splendid Australian lavender, large tall and a good propagator. Janice attracts very much attention evcen though it is very new. The color is unusual. Perhaps the finest new commercial variety is Royal Lavender, a rose mauve shade. It is among the most beautiful of all and should become very popular. Jubilee is a huge flower on a tall spike. The substance is only fair but it is a grand show flower. Oneca impressed us as did Wyoming. The latter is unusual with about half the flower a creamy yellow. It scarcely belongs in the lavender class. Locarno is quite unusual. Mrs. Herbert Hoover was one of the best introductions of the past season. It is very tall, of heavy substance and fine color, being heavily blotched. La Petite from the same originator is an exquisite delicate thing. Phrania is of the same unusual shade as Mrs. Hoover and Janice. It was good. J. S. Wallace and Lady van Horne from the same originator are similar. Both are of good substance, clear throats, and heary spikes, but seem to bend easily, and not as large or as well placed as one could wish. Dorothy Simpson is a different and beautiful variety. Mary Frey still holds its place as supreme early commercial variety.

\section{SMOKY}

We still think Mother Machree the most beautiful of all smoky varieties. It is soft, luminous and most exquisite. Besides, about as strong a grower as we have. Marmora, however, will give a heavier spike, and is supreme among any varieties for exhiibtion. The grand spikes open eight to twelve florets at a time. There are many new Scotch varieties of merit, in this class. Duchess of York and Carrick among the older ones; Rosella Amos, Comrade, Field Marshall, and Sultan are splendid and well worth growing. All are quite distinct. And from New Zealand we have Autahi, Tutanakai, Hinemoa and others-all very fine. From France, Roi Albert and Emile Auburn. From all this list, it seems hard to believe that our own country is not behind in distinctive originations this class. But this is not the case. Jane, a new rich smoky prim from Canada is excellent and in a class by itself in color. Then we have Dusky Queen, an improvement on the old Prince of India-tall strong and large. Rose Tint, as the name implies. Brown Wings, almost really brown. Bronze Maid is almost bronze with a rich throat. The substance leaves something to be desired but it is well worth while. Rosewood seems an improved London Smoke. Grey Knight is almost truly grey. The Emir leaves much to be desired in height but is worth while for its color. Van is a sort of tan shade with purple throat. You either like it or you don't. Damascuswere it not for Mother Machree would be an outstanding variety. It is good. 
Golden Brown is an unusual and beautiful color. Lavender Bride is a smoky lavender if unusual beauty. There are few flowers where such shades may be found, and in the gladiolus, they are so prominent that they have doubtless done much to further the cause of this beautiful flower.

\section{WHITE}

There are a number of outstanding white varieties, both from this country and from Europe. Albatross still holds its place for purity of color, length of spike and size, though the form could be improved upon. Mammoth White is a still larger flower and comes placed in a double row on the spike, but the florets are sometimes crowded. This fault the past season may have been due to the drought. The color is very fine, but not quite so pure as Albatross. Johnkeer van Tets, is somewhat similar to Albatross but beter form. It comes scarcely as large however from small bulbs and as the flower ages it sometimes shows color. A white which we observed for the first time this season was Perfecta. This is a most attractive flower of good substance and exquisitely frilled. It is a fine grower and propagator too, while the spike, flower and color are quite ideal. Matilda Ann is a fine white of unusual form, giving a lacinated impression.

Coronado makes a great flower but does not open many florets at a time. It is difficult to propagate in our experience. Anna Pfitzer on the other hand is a splendid flower and propagator and is a fine large creamy flower on a good spike. We like it very much indeed. Fanny Crosby is a splendid cream also. We won first prize at Springfield this season for the spike with the most buds and blooms. It would make a grand exhibition variety. Another new one that is good-among the finest blotched whites is Mrs. F. E. Bennett. This is very tall, clear and of good substance. Anna Mason is a good creamy white. Bridal Veil and Milady Imogene are good commercial varieties. White Orchid a very large winged flower is particularly attractive. And Lillian Gish has attractive form of florets of fine clear color but sometimes comes very crooked. Irer'l is so pure and soft that it is much admired. Mrs. Catherine Edwards is a heavy spike of excellent color but has its faults in placement. It is excellent for exhibition when carefully bloomed. Solenge is an exquisite cream tinted white. It, too, does not always come perfectly placed. Sylvia West widely known for being so high in price at introduction, is a good color and of attractive form but the size and height are negligible. Midbloom is a most beautiful thing with a scarlet blotch on the lower petals, which seems to reflect on the upper side of the flower. We are very fond of it. Katinka too is a blotched white of exquisite form. Not especially large but we like it very much. Lotus is short but good sized and makes several spikes from a bulb. The color reminds us of Olive Goodrich. Santa Barbara is a beautiful tinted cream of fine ruffling and substance. Helen Wills is one of the most attractive commercial whites. It has a lemon throat but a long selnder spike. With us, however, bulblets do not germinate at all well. Mrs. Killion is a grand flower but the spike crooks terribly. Olive Goodrich with its exquiste pink edge is and should be, in great demand commercially.

\section{ORANGE}

There are sereral outstanding varieties in this shade. Mrs. S. A. Errey is doubtless the finest exhibition type but is rather an orange salmon. The huge florets on a tall heavy spike always attract much attention. It should be opened inside however, as the color fades in the sun. La Paloma is more of a commercial variety of pure sparkling orange, tall and well placed. It should be grown abundantly. Then there is Gladdie Girl an exquisite blend of yellow and bittersweet orange, on a tall heavy spike. It is more than worth while. Sonny Boy is good too. Mandarin, of Crow's is a most striking yellow throated orange, with perfect form and spike. It is among the finest of all. J. H. McFarland is somewhat the color of Helen Howard. It seemed to be larger and heavier. Tolsa, a new one was an attractive blend of color. Orange Wonder is good. Orange Fire was as brilliant as its name would indicate. Oranion is a good orange with pointed petals. Senorita is an unusual flower with long slender petals and when a number of florets are open it makes a huge cluster of color. It is much admired. 


\section{PURPLE}

There are, comparatively speaking, new good varieties in this color but several of these few are outstanding in the gladiolus world. Ramesses is easily the finest tall purple we have grown. The extreme height, size, color-all make it one of the finest new glads. A grand thing indeed. Wodan is an unusual color-a violet blue perhaps better listed under the blues. It is an excellent variety in a color that is in demand. A new variety of the past season is Flor-Rico-a large rose purple of heavy substance and well ruffled. It too was outstanding. Then there was Storm Cloud, a grand spike set with many open florets of clear rich purple,-very good indeed. Troubadour-a reddish purple is perhaps the finest in this color. It should make good commercially. Mona Cree is somewhat like Anna Eberius, being perhaps an improvement on that variety. The older Aida still holds its own as a rich color and is very early.

\section{RED}

The first red which bloomed this season was the glorious Diablo. Of course it is always the early varieties which are most appreciated, but this would be admired at any time. The rich bright red makes the dark throat appear almost black. O. D. Baldwin is another quite similar to it but later. Both are splendid additions to our list of reds. Lone Eagle is a brilliant vermillion of attractive form. The finest dark red which we grew the past season, different in color from the above however, was Sultan, of Crow's, not to be confused with the Mair variety of the same name. The grand ruffled florets were well set on a splendid spike. It is somewhat of Purple Glory form. Another of Mr. Crow's-Explorer is the finest dark red-that is. "black" variety produced in this country. It opens a large number of well placed florets at a time on spike of a medium length. Fairy Diamond is a fine wide open early red flower. It is among the finest early reds. Captain Kidd is the best laciniated red we have yet grown. Tall, good sized, and of heavy substance is a valuable addition to our short list of laciniated varieties. Thos. Edison remains almost the best of the ruffled reds in the most unusual form. General Canby is very unusual in color-red with a yellow throat, and is much more attractive than it sounds. Chief Joseph is a distinctive brownish red-and ruffled. Red Tornado remians the best red for the late bloom. It is too bad it does not bloom later from early planting. Captain Courageous impresses us very much-it is large rich and of good texture-a stronger grower than Red Tornado. Greatheart is an unusual rose red wtih creamy throat. It makes a grand exhibition spike. Gibralter is an improved Tyrian Beauty of similar color but different form. L. H. Bailey also is of Tyrian rose color with an exceedingly rich blotch. Red Altus is an attractive slender commercial red. It is a fine propagator too. Littlejohn is an unusual deep rose red, heavily ruffled. The spikes are tall and heavy. Finn Malgren and Ronald Amundsen are very similar, being valuable additions to the list of this color. Morocco is a very good dark color. David Airdrie is similar in color to Diener's American Beauty but has a tall fine spike. Gloriosa is an excellent white blotched red, while King George which won first in the red class at Lansing, and second at Springfield, has a creamy blotch and is early. Pfitzer's Triumph is still the most popular of all glads. It is a huge orange salmon making the largest bloom clusters of anything. For exhibition it is supreme, tho in the garden it is not altogether satisfactory. Victor and Ensign are quite similarboth very satisfactory white blotched scarlets. Lady Macbeth is a splendid exhibition variety opening half the spike at once. Excellence is an old one, but the color is among the brightest of any.

\section{PINK}

There are so many excellent pinks that the outstanding ones are difficult to select. It seems however, that Coryphee was the most beautiful bloom we had the past season. Some years it crooks badly, but this year it was perfectly straight. The color is so pure and clear that we immensely admire it. Rosa Belle is on the same order, having the same clear throat, but is more of a rose pink. It does not seem to propagate well however, and is difficult to 
obtain. Mrs. Cuthbertson is a beautiful ruffled flower-fine spike and a clear pink. Nellie, Jessie and Betty are other good Scotch varieties in varying shades of pink. Marvel an unusual shade of pink with a large golden blotch on the lower petals. Prof. Slogteran is a fine open spike of color-one of the particularly admired varieties at the Lansing show. Carolus Clusius is on the whole, one of the finest commercial varieties. We like it better each season for it is quite early, large and a strong grower. Florence L. Barclay and Sweetheart are also good pinks from Holland. Betty Nuthall is among the most outstanding varieties of today. Tall, large and clear, it is grand though quite late. Salbach's Pink is an improvement in growth and reproduction over Rita Beck which it resembles. Scarcely as large, it seems much more reliable, and has the same throat lines that Rita shows. Frank J. McCoy made a fine tall spike but the placement was not as we should have liked. Mapleshade Gem is the best from this originator. It is a fine early ruffled salmon and gives promise of commercial value. Blenn is early and heavily ruffled. The throat could be improved upon. Alice Reid is a fine tall lavender pink-large and a good show. W. G. Welker in begonia rose is among the best in the color. It seemed to wilt in the sun quite badly. Mrs. Leon Ensign, too, nearly comes to a rose shade. It is very strong. Point Twain is an exquisite thingalmost the most beautiful pink we grew. It is a Phipps pink of the most attractive form with pointed petals, and large florets. If a fault, we should have liked the spikes taller. Ella V. Birney was exquisite but short. Dorothy Wood seemed an improved Prince of Wales. Gloriola is perhaps an improvement on Gloriana. It is quite similar in color, and is early. Early Phipps is shorter in spike than Phipps but very early. Angel's Dream has its faults in placement and spike, but the color is exquisite and a well grown spike of this is truly a dream.

Pride of Portland makes up what it lacks in substance by the size and color. It retains both to the very tip bloom. Ripples is somewhat like Mrs. Sisson, but a better grower from bulblets. Coral Lustre is an attractive self colored bloom. Sunshine Girl is an exquisite pink, something like Jennie Lind. Margaret Stevens is a Giant Nymph pink, but opens more florets at a time. It is fine for baskets. Mr. Leo E. Miller was one of the most distinctive varieties we grew this season. The heavy substance ruffling and clear color combine to make it stand among the first. We have grown it for three years, and admire it more this season than any previous year. Sheba makes a grand tall spike. And Oriental silk is indeed silky, and extremely beautiful.

\section{SOME OF THE NEWER PRIMS}

We have not found so many new prims of the past few years, but there are several which are of great worth. First, I would mention Apricot Glow, an exquisite apricot buff on tall spikes and good flowers. It should be a grand commercial variety. Then there is Queen of Bremen a splendid amaranth pink which has won such high awards. Its merit lies in the distinctive color. And Miss Joy, an exquisite pink with a clear yellow throat is of fine size, thought it may lack height. We had it from small bulbs only however. Mandarin of Decorah's is a fine early orange. It was among the first blooms we had. And Sunshine Glow is a most glistening scarlet with a yellow throatone of the brightest spots in the garden. You will like this. Orange Butterfly and Ada De Poy are splendid apricot and yellow varieties of much worth. Copper Gold was exquisite and one of the earliest. Fairy Lanten is one of the finest novelties on the market.

Use more of these exquisite things. For any kind of work they are infinitely more delicate, and splendid effects can be secured with them. 


\section{Moderate Priced Varieties of American Origin.}

A. E. KUNDERD. (Kunderd, 1925, 103 days.) Height 42, size 5. Heavily ruffled salmon with darker blotch in throat. Very strong. Quite a good propagator.

ALBANIA. (Kept, 1921, 86 days.) Height 33, size 4. A very good commercial white. Not a long spike, but excellent placement. Fine propagator.

AMORET. (Kemp, 1925, 93 days.) Height 42, size 41/2. Soft shrimp pink, scarcely any markings. Very good cut flower. Good propagator.

ANCONIA ANTONETTE. (Kunderd, 1926, 96 days.) Height 39, size 5. Somewhat like the above. Salmon pink of good form and also a nice cut flower. Good propagator.

BALBOA. (Briggs, 1926, 93 days.) Height 36, size 4. Soft pink and yellow, very nice coloring. We think it quite good, and is a good propagator.

BEATRICIA. (Ellis, 1927, 94 days.) Height 34, size 4. Quite a good red with wide open florets of good size. Something of an improvement on Beatriz Michelena. Fairly good propagator.

BEAUTY WAVE. (Kunderd, 1927, 89 days.) Height 35, size 31/2. A very attractive ruffled yellow, tinted pink. Fair propagator.

BENGA LTIGER. (Pratt, 1921, 94 days.) Height 40, size 5. Oriental red with almost black stripes, which merit it its name. One of the most popular of the unusual varieties. Good propagator.

BERNARD SHAW. (Diener, 1922, 94 days.) Height 45, size 5. Light lilac, sometimes streaked darker. Extra heavy substance which holds in any kind of weather. Prolific but not a good germinator.

BETTY JOY. (Bill, 1924, 90 days.) Height 38, size 4. Very soft pink shaded lighter. We liked this variety better this season than any time before. It opens several florets at a time and they are always well placed. Seems a good propagator.

BLASCO IBANEZ. (Diener, 1923, 93 days.) Height 36, size 31/2. Fine clear purple of good placement. Not an extra good grower, but seems to propagate quite well. Still worth while.

BLUE TORCH. (Hornberger, 1926, 88 days.) Height 37, size 4. A good commercial blue. Called an improven Eubank. Always straight. Fairly good propagator.

BOBBY. (Kunderd 1925, 98 days.) Height 40, size 5. Strong rose red with deeper blotches. A fine cut flower variety of bold coloring. Strong and rapid propagator.

BON ECHO. (Bonsteel, 1926, 85 days.) Height 40, size 5. A good cream color with a throat which does not improve its beauty. Fine substance and form on good spike. Fine propagator .

BREAK O' DAY. (Bill 1924, 78 days.) Height 38, size 41/2. A good willowy spike well set with clear pale pink blooms with darker throat lines. A leading early cut flower. Heavy propagator.

CARDINAL PRINCE. (Kunderd, 1924, 86 days.) Height 37, size 4. Very nice clear cardinal red. Seevral florets open well placed on a medium length spike. Very good propagator. 


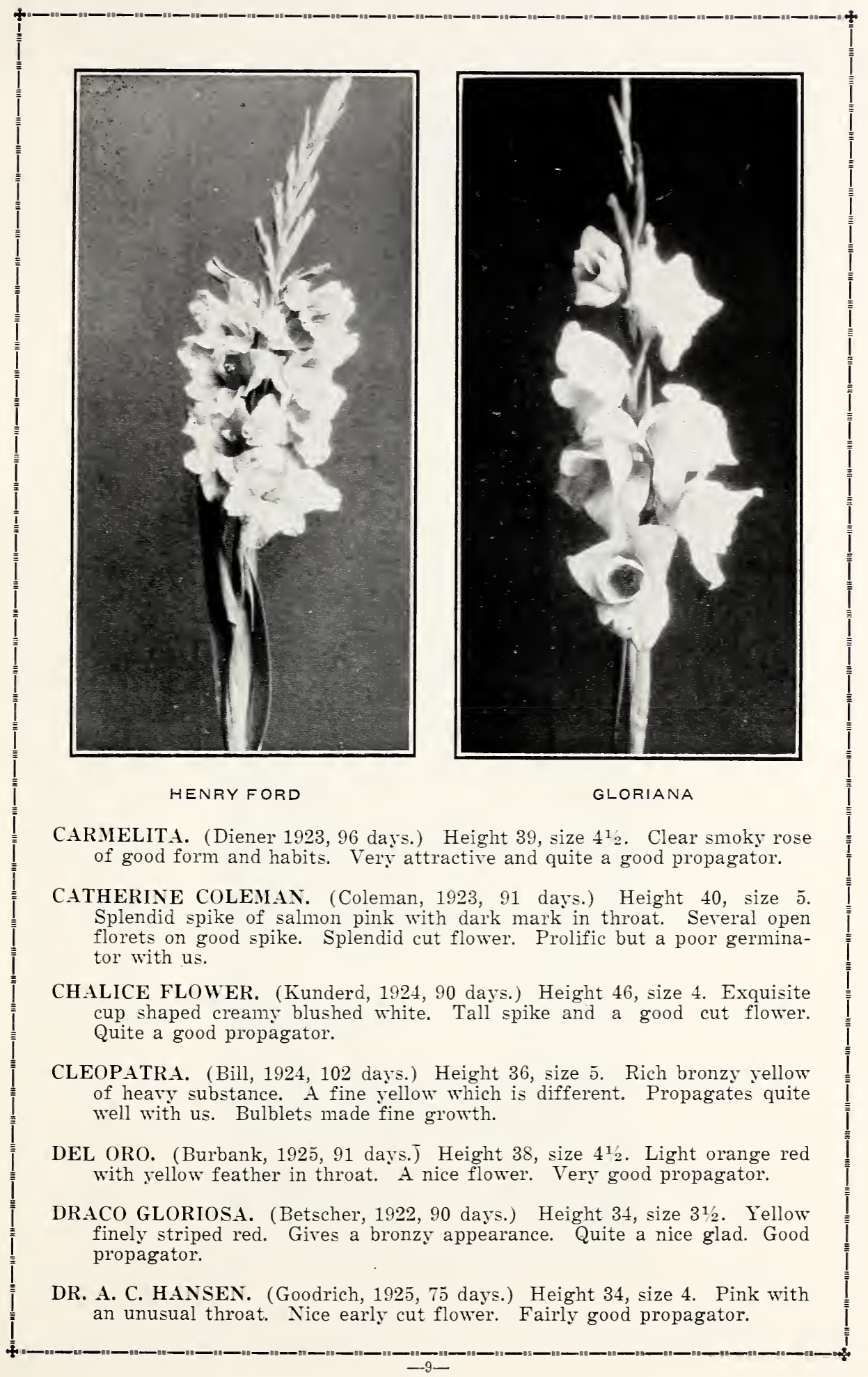


DR. F. E. BENNETT. (Diener, 1922, 93 days.) Height 40, size 5. One of the finest reds-a clear self colored scarlet. Good grower and fairly good propagator. One of the most popular varieties.

DR. LINCOLN COTHERAN. (Diener, 1923101 days.) Height 42, size 41/2. Another very attractive smoky glad. Excellent cut flower, and very popular with visitors. Good propagator.

ELDORA. (Kemp, 1924, 95 days.) Height 42, size 4. Light pink and buff. A very good cut flower on fine spikes. Good propagator.

ELIZABETH. (Meader, 92 days.) Height 39, size 41/2. This variety is most never seen but its fine color of pink to a clear throat has considerable to recommend it. It was sent us by a friend some years ago, and we have never seen it elsewhere. A nice glad, but not a very good propagator.

ELIZABETH SWARTLEY. (Swartley, 1927, 80 days.) Height 36, size 4. A sport of 1910 Rose, but the color is a soft salmon pink to a pure white throat. Very valuable cut flower variety. Good propagator. Makes large bulblets.

ELIZABETH TABOR. (Hinkle, 1921, 78 days.) Height, 43, size 5. A tall slender Pendleton, with pointed petals and several weeks earlier. Very valuable cut flower variety. Good propagator.

ELOMA. (Ellis, 1928, 81 days.) Height 38, size 41/2. A beautiful almost clear pink which, if it always came straight, would be very valuable cut flower. Fine florets and excellent substance. Seems quite a good propagator.

ERNESTINE. (Ellis, 1928, $11 \dot{5}$ days.) Height 42, size 4. Peach red with white throat. Sparkling texture. Very fine spike.

EXCELLENCE. (Kunderd, 1927, 84 days.) Height 40, size 5. Very clear self colored scarlet. Unusual smooth texture. Very striking and beautiful. Prolific but not a very good germinator.

FONTAINE. (Coleman, 1923, 84 days.) Height 35, size 31/2. Exquisite blend of pink and cream, well ruffled. A most attractive florists' flower. Very heavy propagator.

FROST KING. (Ellis, 1928, 81 days.) Height 34, size 4. Soft rose pink with white throat. Blooms over a long period of time. Heavy propagator.

FULD'S FAVORITE. (Kunderd 1927. 120 days.) Height 37, size 4. Light lavender rose with lighter throat. Very nice color and good cut flower variety. Fairly good propagator.

GEORGE J. JOERG. (Joerg, 1926, 93 days.) Height 36, size 4¹/2. Very rich pink with carmine marking. Strong grower. A fine glad not well enough known. Fair propagator.

GERALDINE FARRAR. (Diener, 1922, 96 days.) Height 35, size 4. An older blue, but still very good. Fine soft color and some seasons is really fine. Has won a number of awards. Growth is not extra strong but it propagates quite well.

GIANT NYMPH. (Coleman, 1920, 90 days.) Height 44, size 41ㄴ2. A standard rose pink which is very popular. Cream throat. Fine cut flower spike, and excellent placement. One you will like. Good propagator.

GLORIANA. (Betscher, 1922, 90 days.) Height 40, size 4. Perhaps the most beautiful color to be found in glads. Exquisite pure salmon to a yellow throat. No markings whatever. The florets do not open widely, but are remarkably like roses. Any size bulb will bloom. Very good propagator. 


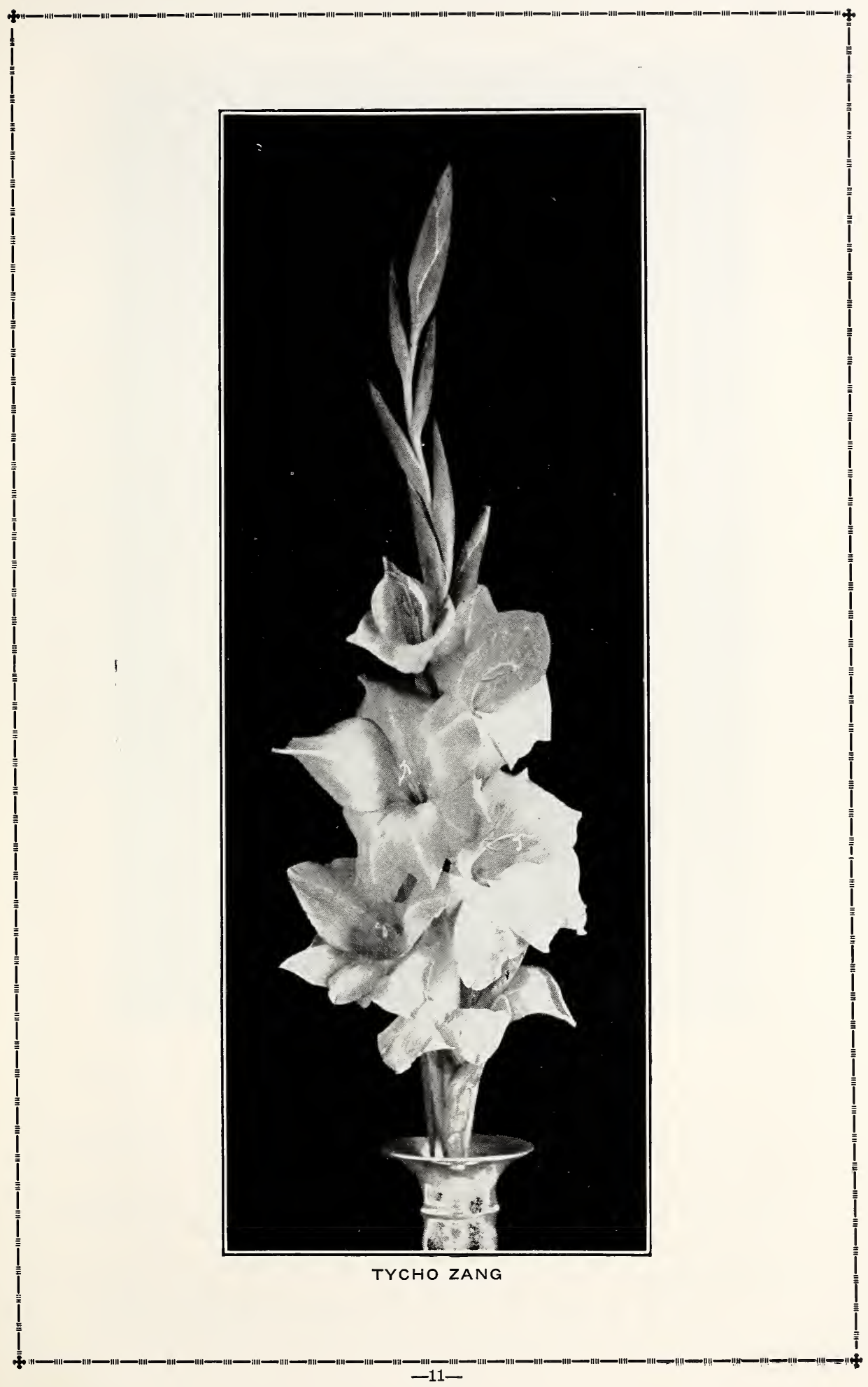




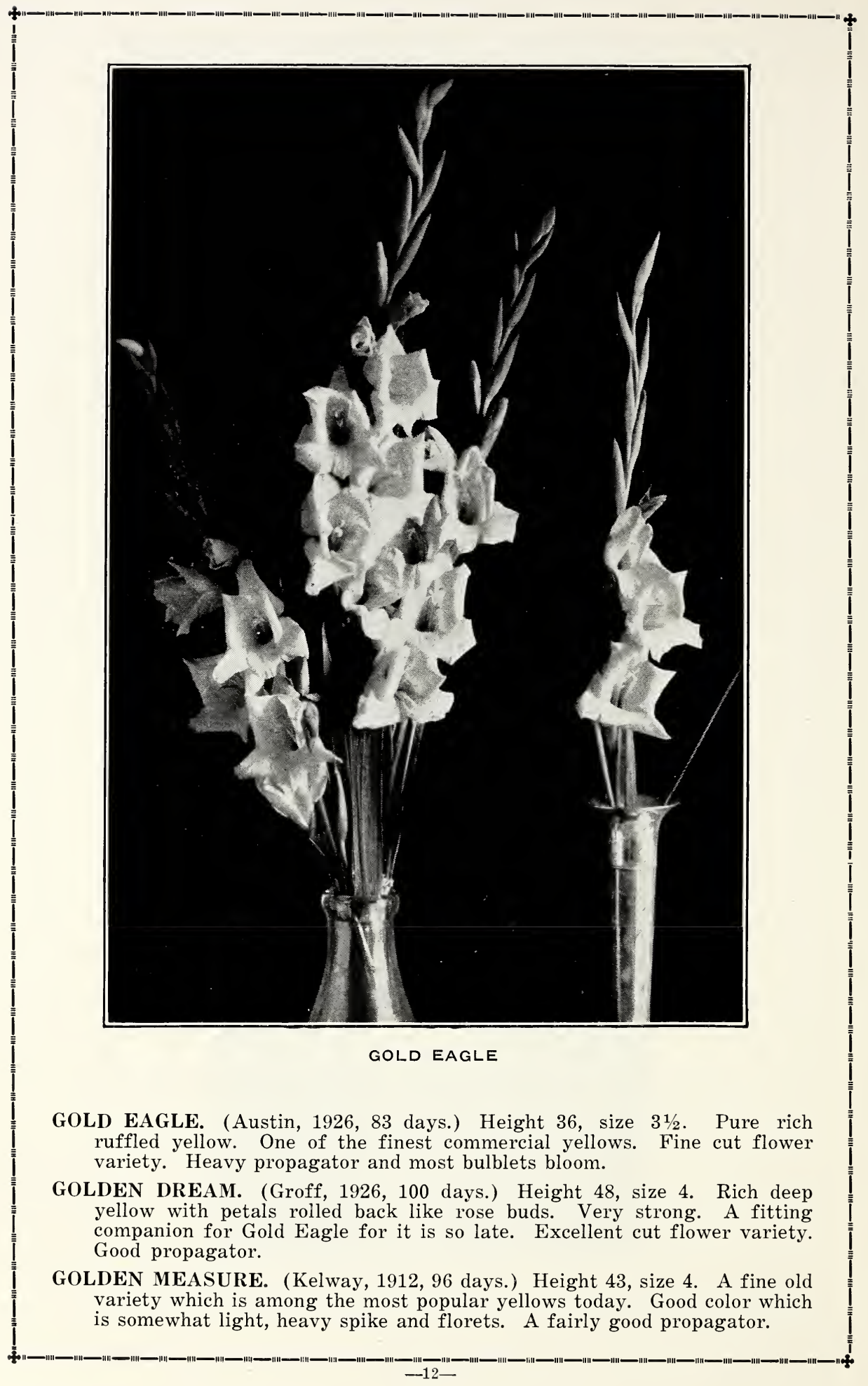


GOLDEN SALMON. (Kunderd, 1925, 93 days.) Height 40, size 4. Very fine color of salmon and yellow. Not wide open, but very beautiful. Good propagator.

GOLDSTONE. (Houdyshel, 1926, 98 days.) Height 34, size 51/2. Unusual shade of pink with glistening texture. Fair propagator.

HAMBURG PINK. (Hornberger, 1927, 81 days.) Height 36, size 41/2. Good clear pink on nice cut flower spikes. Looks good commercially. Good propagator.

HELEN HOWARD. (Austin, 1927, 88 days.) Height 38, size 4. Nice golden buff crushed coral. Sometimes streaks. Heavy substance and a good strong grower. Fine spikes. Excellent propagator.

HELEN PHIPPS. (Phipps, 1927, 105 days.) Height 40, size 41/2. Slightly deeper than W. H. Phipps and not so large a spike. Earlier and not so large. Good propagator.

HELEN WILLS. (Salbach, 1927, 100 days.) Height 46, size 41/2. Fine ivory white with cream throat. Slender cut flower spikes. Good grower and prolific, but not a good germinator with us.

HENRY FORD. (Diener, 1922, 95 days.) Height 35, size 4. Very rich clear purple. Very poor placement on spike, but an excellent propagator.

HOPE HAMPTON. (Diener, 1925, 98 days.) Height 42, size 4. Unusual shade, strawberry pink, with peach red. Several open. Variable. Some seasons excellent. Good propagator.

KIVA. (Burbank, 1925, 96 days.) Height 40, size 5. Yellow pink, on good spike, and good form. Very prolific.

IWA. (Burbank, 1925, 96 days.) Height 40, size 5. Yellow pink, on good deeper blotch. Very strong grower. Good propagator.

IMPROVED QUEEN OF THE NIGHT. (Diener, 1928, 110 days.) Height 35, size 4. Quite a good dark variety. Very heavy propagator.

JANE ADAMS. (Decorah, 1925, 94 days.) Height 34, size 5. A splendid clear lavender, with yellow throat. Good grower and excellent propagator.

JENNIE LIND. (Decorah, 1922, 88 days.) Height 38, size 4. This strain of the variety is strong growing and makes a fine spike. If you have grown the variety and passed it up because of weak growth and short spikes, we urge you to try this strain. Very good propagator as well.

JOHN TOLAND. (Salbach, 1927, 97 days.) Height 36, size 4. Unusual begonia rose with large deep red blotches on lower petals. Very striking. Fine propagator.

JOHN T. PIRIE. (Kunderd, 1922, 100 days.) Height 38, size 4. Unusual shade of brown, with a darker brown, bordered yellow, throat. Good spikes, and a fair propagator.

JUNIATA. (Kemp, 1924, 90 days.) Height 42, size 31/2. Soft pink and white on good spike. Much admired. Good propagator.

KATYDID. (Carpenter, 1925, 92 days.) Height 44, size 5. Very good pink glad, with large wide open florets. Excellent propagator.

K'S YELLOW WONDER. (Kunderd, 1926, 85 days.) Height 36, size 4. Good light yellow, with deeper throat. Would make good cut flower variety. Heavy propagator. 
KING TUT. (Davis, 1924, 92 days.) Height 36, size 4. Good spike of salmon marked deeper. Fair propagator.

LADY ALICE. (Barber, 1922, 105 days.) Height 42, size 41/2. Excellent orange pink of good spike and placement. Fine color and fairly good propagator.

LAVENDER BRIDE. (Bride, 1927, 92 days.) Height 40, size 5. Beautiful smoky lavender. Fine florets on good spike for cutting. Very popular with visitors. Prolific but a variable germinator.

LILLIAN GISH. (Diener, 1925, 107 days.) Height 43, size 31/2. Pure white with lemon throat. Most attractive form, but sometimes crooks. Good propagator.

LONDON SMOKE. (Diener, 1920, 87 days.) Height 36, size 4. Very good smoky variety. Spike quite pliable. Small bulbs bloom well. Good propagator.

LOCARNO. (McKibben, 1926, 84 days.) Height 32, size 4. Unusual shade of lavender with darker throat. Fairly good grower and propagator.

LONGFELLOW. (Decorah, 1925, 90 days.) Height 38, size 41/2. Clear LaFrance pink with no markings. Stands heat remarkably well. Not a very strong grower but quite a good propagator.

LOS ANGELES. (Houdyshel, 1924, 85 days.) Height 40, size 31/2. Soft orange pink with deeper feather in throat. Often sends up several spikes from the same stalk. Heavy propagator.

LOUVAIN. (Groff, 1925, 96 days.) Height 40, size 4ํㅡ. Excellent tall rose pink. Fine cut flower as all bulbs bloom. Fair propagator. Prolific, but not a very good germinator at times.

MABEL IRVING. (Briggs, 1925, 85 days.) Height 38, size 4. Clear pink, slightly ruffled. A good cut flower. Good propagator.

MARIE KUNDERD. (Kunderd, 1918, 78 days.) Height 36, size 41/2. Pure ruffled white with faint pink line on lower petals. One of the most beautiful whites. Not extra strong but a good propagator.

MARINA. (Kemp, 1925, 97 days.) Height 40, size 41/2. Excellent commercial orange. Very good spike for cutting, and a strong grower. Very heavy propagator.

MARY FREY. (Gelser, 1926, 85 days.) Height 39, size 5. One of the finest, if not the best early lavender. Color like Mrs. Peters, but weeks earlier. Good grower and fine propagator.

MARIE JANE. (Kunderd, 1925, 93 days.) Height 35, size 41/2. Large lavender pink shading to white. Something on the order of Dorritt, but better. Streaks under certain conditions, but when clear is very beautiful. Fairly good propagator.

MAURICE FULD. (Gage, 1922, 96 days.) Height 37, size 51ㄹ․ Rose pink, with darker throat. Requires good size bulbs to throw spikes. Great exhibition flower. Fair propagator.

MERCED. (Briggs, 1925, 85 days.) Height 38, size 31/2. Soft salmon pink on wirey stems. Good florists' flower. Excellent grower and propagator.

MINUET. (Coleman, 1925, 100 days.) Height 40, size 5. One of the finest lavenders grown. Clear distinct and beautiful color on fine spikes. Very slow propagator. Prolific, but a poor germinator. 


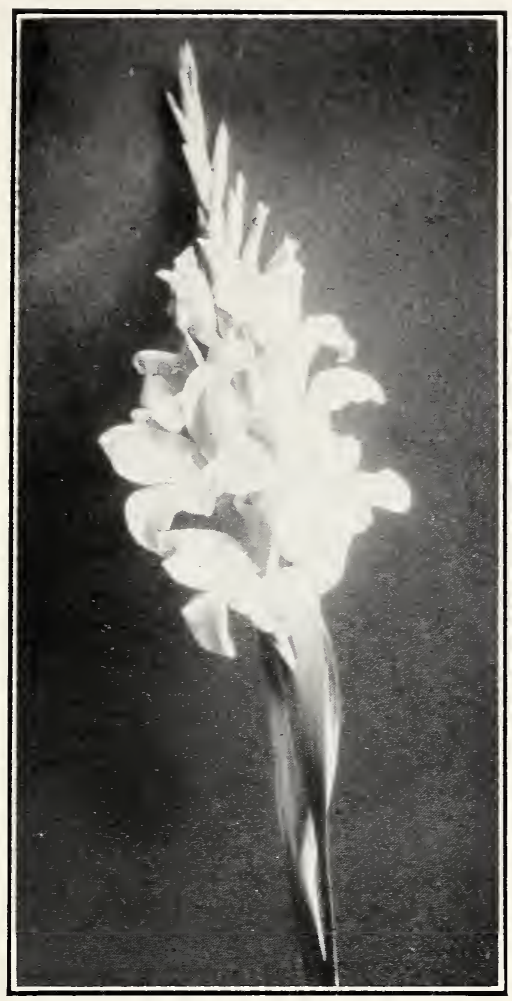

One of the finest glads of all times. Plant it for exhibition or for cut flowers-you will not discard it for years.

\section{CATHERINE COLEMAN}

MISS MADISON. (Hunt, 1923, 98 days.) Height 36, size 4112. Soft pink, an improved Panama. Very good cut flower variety but a little soft. Good propagator.

MONTE CARLO. (Pety, 1928, 91 days.) Height 36, size 4. Excellent salmon orange on good spikes. Good propagator.

MR. W. H. PHIPPS. (Diener, 1922.) A late variety, which did not get into bloom this season, before frost. One of the greatest of all glads, all spikes with twelve to twenty huge salmon florets open at a time. The monarch among glads. Fairly good propagator.

MRS. F. C. HORNBERGER. (Hornberger, 1925, 107 days.) Height 45, size 4. Pure white, nicely frilled. One of the strongest white varieties. Very good propagator.

MRS. F. C. PETERS. (Fischer, 1921, 98 days.) Height 42, size 41/2. Tall rose lavender with deeper blotch. The finest commercial late lavender generally grown. Excellent form. Prolific but not the best germinator.

MRS. J. K. ARMSBY. (Diener, 1920, 90 days.) Height 36, size 41/2. Good early salmon, with several florets open. Striped deeper salmon. Good propagator.

MRS. LEON DOUGLASS. (Diener, 1920, 94 days.) Height 55, size. 6. Salmon with darker stripes. The grandest glad in the garden, and one of the most popular for all purposes. Excellent propagator. 
MRS. M. J. KILLION. (Fischer, 1926, 110 days.) Height 38, size 5. Huge creamy white. When this variety comes with a straight spike it is sensational. Give it plenty of water. Quite a good propagator.

MRS. NEWALL VANDERBILT. (Diener, 1921, 97 days.) Height 38, size 4. Clear salmon somewhat ruffled. Clean grower and good propagator.

MRS. P. W. SISSON. (Coleman 1925, 95 days.) Height 40, size 41/2. Pure soft cameo pink of exquisite form. One of the strongest growers in the garden. One of the finest glads in existence and will be grown very widely when plentiful. Excellent propagator though the bulblets are small and do not make much growth the first season.

MRS. RICHARD LOHRMAN. (Diener, 1920, 99 days.) Height 35, size 4. Cream pink, and an exquisite blend of color. Frequently crooks, but a fine flower when straight. Good propagator.

MRS. W. E. CLARK. (Fischer, 1924, 93 days.) Height 43, size 3. Light salmon with flame blotch. Very slender straight spike-nice for baskets. Good propagator.

MRS. W. T. GIBBS. (Gibbs, Thacker, 1927, 90 days.) Height 40, size 4 . A nice pale pink with deeper blotches in throat. Fine spike and form for florists. Excellent keeping qualities. Good propagator.

MURREL LITER. (Goodrich, 1925, 92 days.) Height 38, size 4. Very good massive pink. Nice spike. Strong and heavy propagator.

NANCY HANKS. (Salbach, 1924, 91 days.) Height 35, size 4. A fine cut flower variety. Soft yellow and apricot. Heavy texture, florets perfectly placed. Very even grower. Good propagator.

NORMANDY. (Carpenter, 1926, 80 days.) Height 38, size 4. Quite a good early orange. Has a jarring throat, but general color is very good and it is of good spike and texture. Good propagator.

OLIVE GOODRICH. (Goodrich, 1926, 94 days.) Height 39, size 4. Exquisite white with pink edge all around flower. One of the finest cut flower varieties, for form is always perfect and spikes are always good. Excellent propagator with us.

OPALESCENT. (Bill, 1922, 87 days.) Height 35, size 41/2. Very good commercial lavender. Easy grower and good propagator.

OPAL LONG. (Goodrich, 1926, 94 days.) Height 40, size 4. Good heary smoky glad. Perhaps the color is a bit depressing, but at least it is unusual. Well liked. Fairly good propagator.

ORANGE FLAME. (Kunderd, 1922, 99 days.) Height 41, size 41/2. Large orange scarlet. Heavy foliage, spike and flower. One of the good ones which is not well enough known. Fair propagator. Sometimes does not germinate well.

ORIENTAL GEM. (Goodrich, 1925, 86 days.) Height 34, size 4. Another fairly good smoky variety. Has a faded effect, but is better we think, than Fallen Leaf which has been quite popular. If you care for smoky colors, you will like this one. Fairly good propagator.

ORCHID LADY. (Spencer, 1927, 79 days.) Height 40, size 51/2. Light lavender streaked darker. When opened indoors and clear, it is beautiful, though the substance is but moderate. It is about the largest early lavender, and is a heavy propagator.

OSALIN. (Salbach, 1926, 92 days.) Height 39, size 4. Very good salmon with practically no markings. Good substance. Strong grower and very good propagator. 
PEACH ROSE. (Kunderd, 1919, 84 days.) Height 37, size 31/2. Soft rose pink with very rich carmine pink blotches. Very popular for cutting. Fairly good propagator.

PEARL OF CALIFORNiA. (Kingsley, 1926, 96 days.) Height 38, size 5. Heavy spike of light pink striped deeper. Quite outstanding and very popular. Fairly good propagator.

PERFECT BEAUTY. (Miller, 1926, 95 days.) Height 34, size 31/2. Very well set spike with good textured flowers. Should make quite a good cut flower. Fair propagator.

PINK MARIE. (Ellis, 1927, 85 days.) Height, 36, size 4. A Marie Kunderd pink-same form and earliness. Very good commercial pink and a good propagator.

PRESIDENT HARDING. (Partain, 1928, 87 days.) Height 35, size 4. Deep Tyrian rose with lined throat. Good cut flower with many florets open but lacks length of spike. Good grower and propagator.

PRIDE OF WANAKAH. (Chriswell, 1925, 93 days.) Height 37, size 5. Excellent lavender rose of wonderfully rich color. Habits of spike are fair, but it is one of the finest commercial varieties. Tremendous propagator.

PRIMROSE PRINCESS. (Salbach, 1927, 102 days.) Height 41, size 41/2. Very good yellow with slight carmine in throat. Excellent cut flower variety, but some florets are not well placed. Should be quite a leader among commercial yellows however, in spite of that for growth is excellent and it is a fine propagator.

PRINCELY. (Kemp, 1924, 92 days.) Height 42, size 5. Very fine tinted white-excellent for cut flowers. Large lily shaped florets of good substance. Good propagator.

PURPLE QUEEN. (Kunderd, 1925, 98 days.) Height 40, size 41/2. Excellent ruffled purple of good habits. Very popular and a fine cut flower variety. Good propagator.

QUINTON. (Kemp, 1923, 82 days.) Height 35, size 5. Coral, shading deeper. Willowy spike, sometimes lacking in length, but very good for florists. One of the best early pinks. Heavy propagator.

QUEEN MARY. (Salbach, 1927, 95 days.) Height 37, size 31/2. Peach red shading lighter. Ruffled and a good spike. Excellent propagator.

RAVENNA CREAM. (Austin, LeGron, 1927, 102 days.) Height 38, size 41/2. Quite a striking flower, of cream with red blotches on lower petals. Good size and texture. Quite a good propagator.

RED GLORY. (Piper and Ellis, 1928, 100 days.) Height 40, size 5. Rich crimson sport of Purple Glory. A grand cut flower, and very popular with all who see it. Very rich. Fair propagator.

RICHARD DIENER. (Diener, 1921, 101 days.) Height 37, size 4. Beautiful pure salmon--a yellow pink-with yellow throat. Good spike with many florets open at once. Particularly beautiful. Fair propagator.

RIPPLING WATERS. (Ellis, 1927, 80 days.) Height 36, size 5. Fine cream suffused pink. Perfect exhibition form-many florets open at once. Good propagator.

RITA BECK. (Fischer, 1926, 110 days.) Height 40, size 5. Pure shell pink with scarlet lines on lower petals. Very large flowers and a strong grower Has been considered the finest pink. Rather variable with us as to spike, and not an extra good propagator some seasons. 
ROSE ASH. (Diener and Metzner, 100 days.) Height 38 , size $3 \frac{1}{2}$. The old standby in ashes of roses. The best known smoky variety and the one that has done more than any other to popularize this type. Habit not always perfect, but good color. Good propagator.

ROSE MULBERRY. (Austin, 1927, 94 days.) Height 38, size 4. An improved Rose Ash in form and spike. Also larger. Good propagator.

ROSE O' CALIFORNIA. (Houdyshel, 1927, 97 days.) Height 37, size 4. A good rose color, with fair spikes and good florets. Fairly good propagator.

RUBY. (Kirchoff, 102 days.) Height 35, size $3 \frac{1}{2}$. Very rich ruby red. Grow it for its color. Fair propagator.

RUFFOLACE. (Kemp, 1924, 90 days.) Height 36, size $3 \frac{1}{2}$. Very good lacinated and ruffled pure white. Good grower and excellent propagator.

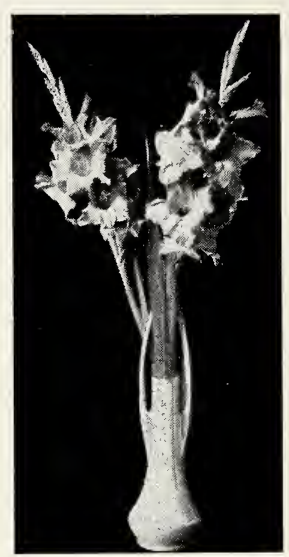

ROSE ASH

RUTH FIELD. (Kunderd, 1927, 84 days.) Height 36, size 4. Soft lavender with cream throat. Very valuable to combine with the yellow prims as the spike is tall and slender and it blooms a long time. We like it very much and would not want to be without it. Good propagator.

SANTA BARBARA. (Briggs, 1925, 102 days.) Height 36, size 41/2. Heavily ruffled cream tinted pink. Very heavy substance on good spike. We liked it very much this season. Good propagator.

SAHABAND. (Salbach, 1925, 92 days.) Height 40, size 5 . One of the best in the shade. Dark Bordeaux. Excellent spike and form. Prolific but not very good germinator.

SMOKY. (Hutt, 1927, 92 days.) Height 40, size 5. This variety is identical with Sacajawea, (Pratt). Fine coppery bronze on tall spike which frequently crooks. Fades in the sun, but indoors comes very clear. The buds are excellent color. Good propagator.

SOPHIE FISCHER. (Fischer, 107 days.) Height 38, size 41/2. A very fine cut flower pink. Perfect form and substance. This variety should be much better known, in spite of the fact that it is not an extra good propagator.

SOVEREIGN. (Vaughn, 1923, 90 days.) Height 39, size 4. An improved Baron Hulot in growth and spike. Quite similar color but a bit lighter. Excellent propagator.

STAR OF THE SEA. (Ellis, 1927, 85 days.) Height 40, size 5. Peach red with brownish markings. Very wide open, star shaped flower of great beauty. Good propagator.

STELlA. (Pety, 1928, 95 days.) Height 36, size 4. Clear white with cream throat. Good spike wtih several open. Good grower and propagator.

SUPERBA. (Coleman, 1922, 84 days.) Height 36, size 4. Good carmine red with penciled throat. Nice early cut flower, but not an extra strong grower or propagator.

SWORD OF MAHOMET. (Ellis, 1927, 96 days.) Height 42, size 31/2. Unusual dusky color, a brownish shade. Splendid spike but florets do not fill it out well. Good propagator. 
THE SWAN. (Miller, 1926, 111 days.) Height 34, size 31/2. White, on good spike and well arranged. Fair propagator.

SUNNYMEDE. (Fischer, 1923, 88 days.) Heigh̆t 35, size 3. Orange with deep orange blotches. If this variety were larger it would be quite outstanding. Good for baskets as the color shows up well. Good propagator.

TRITOMA. (Stevens, 1928, 76 days.) Height 40, size 4. Soft blush pink on cream ground. One of the good early cut flowers. Rather soft but nice flower. Good propagator.

TYCHO ZANG. (Austin, 1924, 100 days.) Height 36, size 5. A good salmon pink which is a popular cut flower. Heavy foliage.

VEILED BRILLIANCE. (Austin, 1927, 96 days.) Height 40, size 5. Huge spike of rose, tinted greyish blue. Merits its name. Very popular and a very good propagator.

VESUVIUS GLOW. (94 days.) Height 37, size 4. Unusual shade of something like orange rose, tinted blue. Very attractive. Seems to be a poor propagator.

W. A. SISSON. (Diener, 1925, 96 days.) Height 36, size 41/2. Beautiful white of nice form. Not a pure white. Good grower and seems to be a fair propagator.

WIAWASSEE. (Kunderd, 1927, 90 days.) Height 36, size 5. Light salmon striped deeper. Very clear colors. Attracts a lot of attention, and is very attractive. Wide open flower. Fair propagator.

WILLIAM BOOTH. (Kunderd, 1927, 96 days.) Height 39, size 41/2. Unusual shade of deep rose which is very attractive. Fair propagator.

WILLIAM KENT. (Diener, 1920, 118 days.) Height 34, size 4. Rich shell pink wtih golden throat. Heavily ruffled and many florets open at a time. Does not hold up well when cut, but a beautiful flower, one of the most exquisite of all ruffled varieties. Fair propagator.

WHITE ORCHID. (Bill, 1926, 80 days.) Height 37, size 5. Fine creamy white of orchid form. An excellent variety, strong and a good propagator.

WHITE STAR. (Hornberger, 1927, 120 days.) Height 37, size 4. A fine late white of good exhibition form. Several open at a time, and color is good. Cream throat. Good propagator.

"Your bulbs were the best I received last season" writes Dr. Cooper of North Dakota under date of October 20, 1929. "That's why I want to deal with you this season." 


\section{The Newest of the Newer Glads from America-}

AMBRosiA. (Kunderd, 1929.) We have not bloomed this variety, but the description of old rose with yellow blotch, with red in center. Sounds rich. Very good propagator.

ANGELIA. (Parkman, 1925, 112 days.) Height 33, size 31/2. Nice light colored variety. Fine for commercial use.

ANGEL'S DREAM. (Ellis, 1928, 85 days.) Height 36, size 4. Most exquisite La France pink, almost a self color. Fine spikes of attractively formed florets. One of the most beautiful of any that we grow. Fine propagator.

ANTIONE. (Kunderd, 1928, 91 days.) Height 44, size 4. One of the most beautiful of all yellows. Clear, pure and deep. Good spikes, sometimes bent, and medium sized ruffled flowers. Excellent propagator.

BEAUTY'S QUEEN. (Neeley, 1928, 88 days.) Height 35, size 41/2. Soft salmon pink with yellow throat. Very nice flower and fine color. Fairly good propagator.

BEN HUR. (Hornberger, 1929.) Said to be one of the finest purples. We have grown it from bulblets, and find it to be vigorous and strong.

BETTY LUCILE. (Kinyon, 1926, 90 days.) Height 40, size 5. Soft LaFrance pink, sometimes striped deeper. Something on the order of Pearl of California, but a better grower and better substance. A sensation at the Michigan shows. Excellent new exhibition variety. Good propagator.

BETTY McKIBBEN. (McKibben, 1929, 97 days.) Height 34, size 4. Good deep rose with darker mark in throat. Long petals. A good exhibition variety, and a heavy propagator as well.

BETTY NUTHALL. (Salbach, 1928, 121 days.) Height 48, size 5. Clear coral with deeper throat lines. One of the finest new glads in existence. Perfect form and spike. Excellent propagator.

BLEEDING HEART. (Brown, 1926.) Flower similar to Pendleton, but many more open florets. Fine exhibition flower. Fair propagator.

BLENN. (Bales, 1929, 85 days.) Height 38, size 41/2. Heavily ruffled flower. Pink with deeper throat. Excellent substance. Bulblets scarce, but every one grows strongly.

BORROWED GOLD. (Larson, 1929, 84 days.) Height 35, size 4. Nice deep yellow, sometimes tinted. Excellent propagator.

BRIDAL VEIL. (Austin, 1928, 95 days.) Height 36, size 4. Beautiful white, sometimes slightly tinted pink. Beautiful form. Excellent florists' flower. Good propagator.

BRIGHT WINGS. (Neeley, 1929, 88 days.) Height 38, size 51/2. Rich frosted lavender. Beautiful winged florets perfectly placed. A grand flower and fine propagator and grower.

BROWN WINGS. (Hornberger, 1929, 110 days.) Height 30, size 31/2. Most unusual shade of brown. What it lacks in height, it makes up in color. Good propagator.

BRONZE MAID. (Ellis, 1929, 106 days.) Height 32, size 5. Fine clear bronze with almost blue throat. Does not seem to be very prolific, but may be much better another year. 


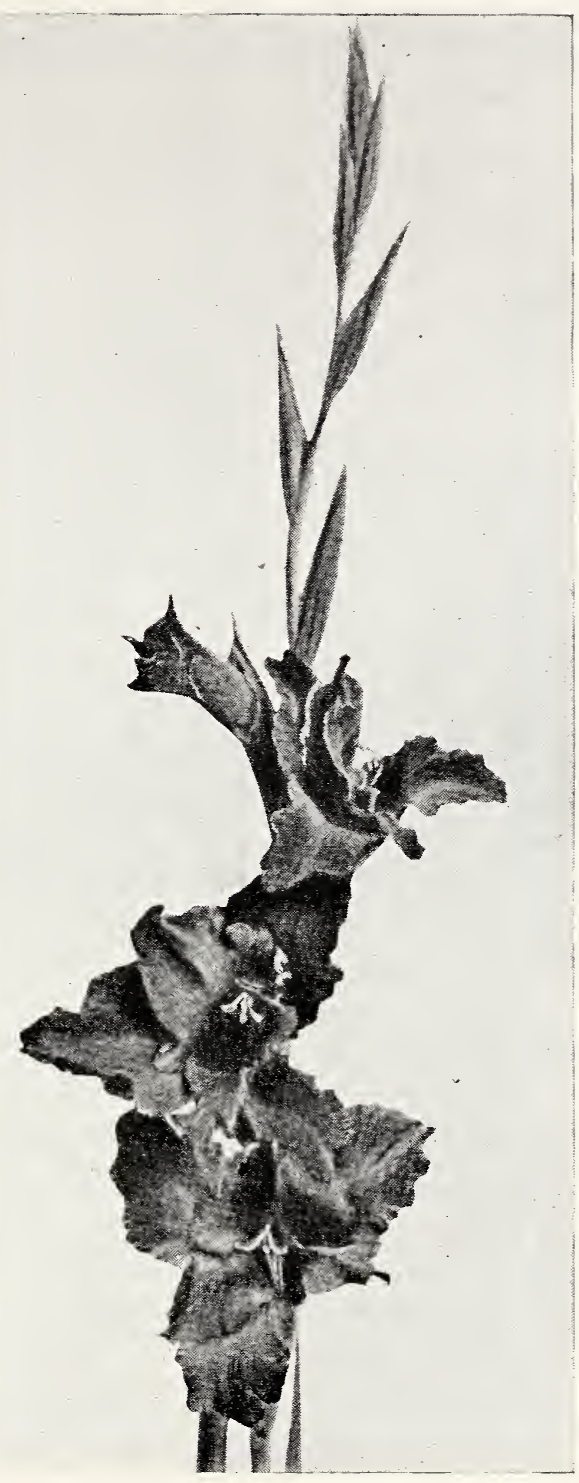

CAPTAIN KIDD

CAPTAIN COURAgEOUs. (Ellis, 1928, 85 days.) Height 36, size 5. Beautiful mottled red, on excellent spike. One of the best reds, a strong grower and fairly good propagator:

CAPTAIN KIDD. (McKibben, 1928, 97 days.) Height 34, size 31/2. One of the best laciniated varieties we have yet found. Excellent dark red color of heavy substance. Strong grower and excellent propagator.

CHAS. CURTIS. (Bill, 1929, 86 days.) Height 38, size 31/2. An attractive shade of buff on good spike. Fairly prolific. 
CHAS. D. THOMAS. (Stevens, 1928, 74 days.) Height 36, size 4. One of the finest yellow varieties, and the finest early yellow we have grown. Soft clear yellow of finest form, occasionally slightly tinted pink which does not impair the beauty. Prolific.

CHICAGO. (Kunderd, 1927, 90 days.) Height 30, size 31/2. Heavily ruffled orange red. Fades in the sun. Fairly good propagator.

CHIEF JOSEPH. (Piper, 1930, 106 days.) Height 36, size 4. An unusual shade of brownish red, well ruffled, good substance, and on a good spike. Good propagator.

COLONEL LINDBERGH. (Harrison, 1928, 97 days.) Height 33, size 4. Soft red with white throat, marked red. An attractive flower of good form. Fair propagator.

CORAL LUSTRE. (McKibben, 98 days.) Height 46, size 41/2. An exquisite shade of coral which we very much admired. Almost a clear color, on fine spike. Excellent propagator.

CORONADO. (Briggs, 1925, 97 days.) Height 33, size 51/2. Huge milk white with great purple blotch on lower petals. Heavy substance and heavily ruffled. Opens few florets at a time, and is a very poor propagator.

CREATORE. (Bill, 1926.) Very large red, with long petals. Attractive shade much admired. Fairly good propagator.

DAINTY QUEEN. (McKibben, 1928, 82 days.) Height 43, size 41/2. Dainty shell pink and white. Excellent placement and well laciniated. One of the most exquisite varieties. Excellent propagator.

DAMASCUS. (Stevens, 1928, 102 days.) Height 37, size 41/2. Another very good new smoky variety. Very unusual color. Quite prolific.

DIABLO. (Salbach, 1929, 76 days.) Height 36, size 4 . One of the finest early reds. Fine crimson with almost black blotch on lower petals. A grand variety which is very much admired.

DIRECTOR. (Crow, 1929). Deep mauve with darker blotches. Said to be similar to Pendleton in form, and very large. Doubtless one of the finest new varieties. Fairly good germinator.

DORCAS ALDRICH. (Dusinberre, 1929.) Height 40, size 5. Clear rose, shaded smoky on the tips. Good form, wide open florets. Quite good and fairly prolific from large bulbs.

DOROTHY WOOD. (Ellis, 1929, 75 days.) Height 35, size 4 . Salmon pink, like Prince of Wales, but has a little more color in throat. Very good cut flower as the foliage does not turn yellow after blooming. Very prolific.

DOVE KILGORE. (Salbach, 1929, 93 days.) Height 32, size 4. Soft pink of grandiflorus type. Very good placement. Prolific.

DR. MOODY. (Kinyon, 1927, 84 days.) Height 36, size 5. A fine early lavender of perfect form and heavy spike. Flakes under some conditions, but an excellent commercial flower in spite of it. Excellent propagator.

DR. S. A. EDMONDS. (McKibben, 1928, 84 days.) Height 36, size 4 . Ruffled deep pink, shading to salmon at edges. Darker throat. Nice cut flower. Excellent propagator.

DUSKY QUEEN. (Martin, Sawyer, 1929, 84 days.) Height 40, size 5. A splendid dusky flower of perfect form and spike. Heavy substance and wide open. Fairly prolific from large bulbs.

EARLY PHIPPS. (Ellis, 1928, 79 days.) Height 36, size 41/2. Slightly deeper than W. H. Phipps, and not so tall a spike. One of the best early glads we have. Perfect form. Quite prolific. 
ELLA DAY. (Carpenter, 1927, 95 days.) Height 36, size $3{ }^{1}{ }^{1}$. Soft pink which has been quite well liked. Fairly good propagator.

ELlA V. BIRNEY. (Ellis, 1929, 84 days.) Height 34, size $3{ }^{1}{ }_{2}$. Very dainty pink which should be nice for cut flowers. Prolific.

EXPLORER. (Crow, 1929, 105 days.) Height 34, size $4^{1 / 2}$. One of the finest black rarieties we have ret found. While not tall, it opens a number of florets at a time; and same are of excellent substance and placement. Fairly prolific.

FAITH. (Kintron, 1929, 100 days.) Height 34, size 4. An exquisite soft blue, similar in shade to Hearenly Blue. Does not fade out when cut, and is an excellent propagator.

FANNY CROSBY. (Carpenter, 1929, 86 dars.) Height 36, size 412. Fine white with cream throat. Many florets open at a time, some generally appearing double. An excellent exhibition variety and quite prolific.

FINN MALGREM. (Decorah, 1929, 96 days.) Height 33, size $3^{1}{ }_{2}$. Soft, slightly ruffled red. Almost pure color. Very nice commercial red. Quite prolific.

FIRST LADY. (Bill, 1929, 92 days.) Height 38, size $3^{1}{ }^{12}$. Soft pink with good spike for cutting. Very prolific.

FLOR-RICO. (Gelser, 1929, 97 dars.) Height 38, size 5. A grand ruffled purple of heary substance and fine form. Should be an excellent commercial variety, though did not seem to make many bulblets from large bulbs.

FRANK J. McCOY. (Briggs, 1928, 102 days.) Height 42, size $4^{1} \frac{1}{2}$. A rich pink of finely formed, wide open florets. Straight spike. Placement was imperfect, but was perhaps due to adrerse season. Good propagator.

FRANK M. SHICK. (Salbach, 1928, 93 days.) Height 37, size 4. Soft clear pink. Should make a good commercial variety. Fairly good propagator.

GALLANT LEADER. (Austin, LeGron, 1926, 198 days.) Height 48, size 5. A rery strong grower and heary spike. A sort of rose pink with darker markings. Fair propagator.

GAY HUSSAR. (Salbach, 1928, 97 dars.) Height 38, size 4. Very brilliant orange red. Darker blotch. An excellent bright colored glad. Good propagator.

GENERAL CANBY. (Ellis, 1929, 92 days.) Height 30, size 4. A brilliant red, marked yellow in throat. Unusual and attractive color combination. One which demands attention. Prolific.

GLADDIE GIRL. (Bill, 1929, 96 days.) Height 48, size 4ํ‥ Bittersweet orange to yellow throat. Very good. Excellent spike and heary texture. Did not make many bulblets from large bulb.

GLORIOLA. (Ellis 1929, 85 days.) Height 42, size 5. A giant in the prim grandiflora class. Color similar to Gloriana, but much more size and not quite so exquisite, but better form. Very strong. Makes huge bulbs, but did not seem to have many bulblets.

GOLDEN BROWN. (Kunderd, 1929, 84 dars.) Height 42, size 31\%2. Heavily ruffled deep mahogany red with really brown throat. Very rich color. Prolific.

GOLDEN GLOW. (Cameron, 1929, 92 days.) Height 40, size 4. Pure, not very deep vellow. Suggestive of Golden Measure, but improved, in spike, color and size. Good propagator. 


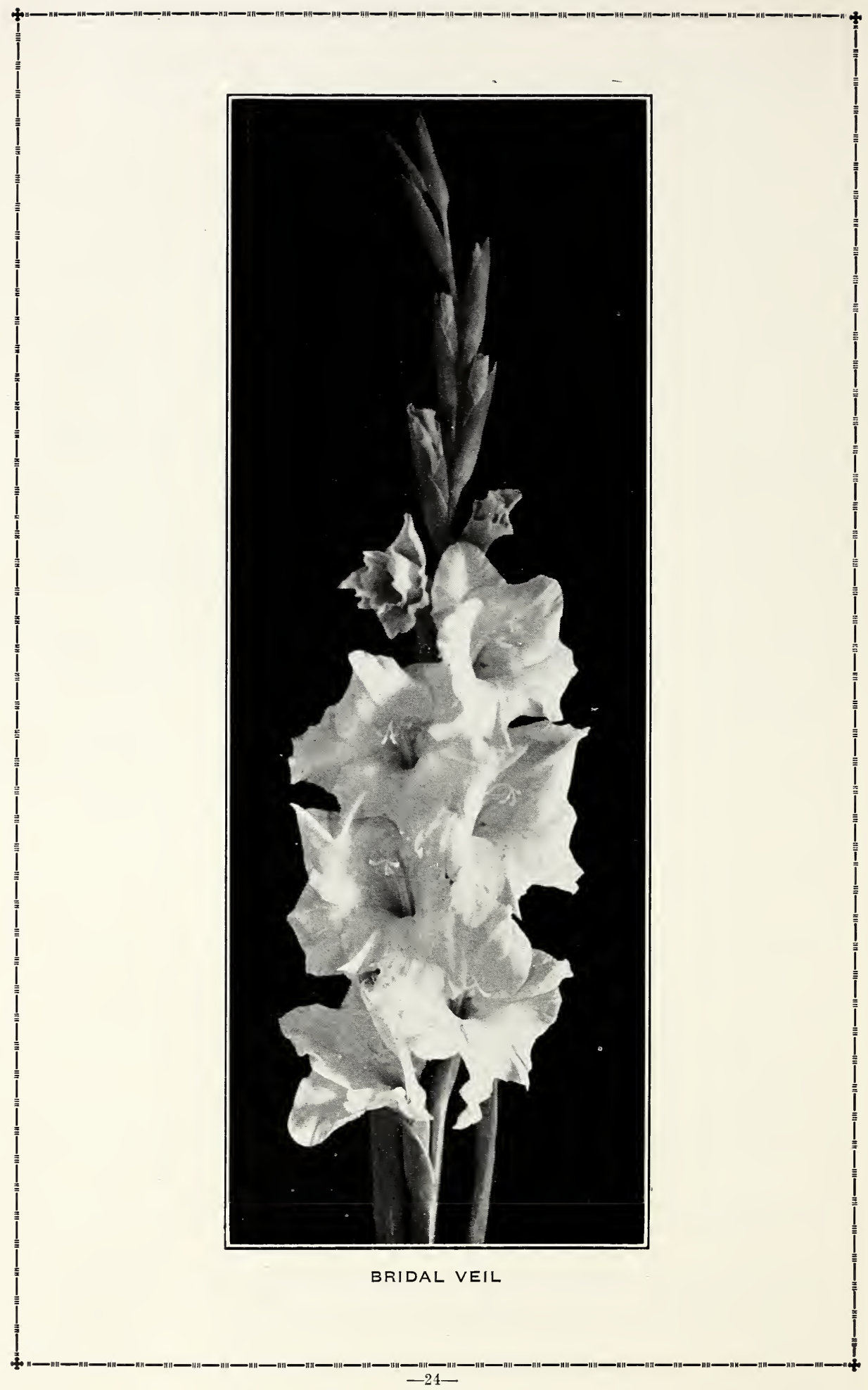


GOLDFINCH. (Crow, 1929.) We have not seen this, but it is said to be one of the deepest yellows produced in glads. Fair propagator.

GREATHEART. (Stevens, 1929, 79 days.) Height 35, size 4. A truly exhibition type of flower. Many rich carmine red florets open at a time, with white throat. Pérfect placement and fairly prolific.

I. O. WOOD. (McKibben, 1928, 84 days.) Height 36, size 5. Clear Tyreian rose blended lighter in center. Wide open florets, reflexed petals-entire flower being very attractive.

ISABELLA. (Pety, 1929, 92 days.) Height 36, size 4. Rose pink with yellow throat. Very nice flower on good spike. Good propagator.

IVER'L. (Austin, 1929, 83 days.) Height 35, size 4. Soft white, even to anthers. Nice grower and good propagator. Good spike and form. We like it.

JANET. (Crow, 1929, 98 days.) Height 41, size 4. A luscious smoky mauve of a shade different than we have ever seen. Wide open florets very little hooded, and quite ruffled. Good propagator.

JANICE. (Carpenter, 1929, 88 days.) Height 34, size 4. An unusual shade of lavender of heavy substance and good spike. Good form. Prolific.

J. ELTON CARTER. (Goodrich, 1929, 102 days.) Height 40, size 4. Clear coral pink with yellow throat. Rich coloring. Prolific.

J. HORACE McFARLAND. (Kunderd, 1927, 97 days.) Height 47, size 4. Beautiful golden orange and yellow. One of the most attractive varieties we grow. Fine placement and substance. Prolific.

J. S. WALLACE. (Groff, 1928, 95 days.) Height 40, size 4. A nice lavender with clear creamy throat. Tall heavy spike which requires staking. A nice glad. Good propagator.

JUBILEE. (Kemp, 1926, 84 days.). Height 37, size 6. Pale rose lavender of fair texture. The largest lavender we grow. Good grower and excellent propagator.

LADY MACBETH. (Ellis, 1928, 94 days.) Height 37, size 41/2. Rose red with speckled throat. Perfect form and placement. An excellent red for exhibition or commercial use. Good propagator.

LADY VAN HORNE. (Groff, 1928, 92 days.) Height 38, size 4. Soft lavender with clear throat. Good heavy spike. Good propagator.

LA PALOMA. (Dusinberre, Gove, 1929, 86 days.) Height 40, size 4. Pure orange, about the clearest and purest of its color. Fine form and spike. A grand commercial orange. Heavy propagator.

LITTLEJOHN. (Stevens, 1929, 89 days.) Height 40, size 5. Heavily ruffled deep rose pink of perfect form and spike. A fine glad which should go far. Prolific.

LILY OF GOLD. (Kunderd, 1928, 84 days.) Height 31, size 31/2. Pure soft yellow, very heavily ruffled and frilled. Exquisite, but not extra strong or large. Good propagator.

L. H. BAILY. (Kunderd, 1927, 81 days.) Height 35, size 4. Rich rose red with deeper blotch. Excellent coloring. Prolific.

LONE EAGLE. (McKibben, 1928, 84 days.) Height 36, size 41/2. A glowing orange vermillion. Brilliant and very attractive. Heavy propagator. 
LOTUS. (Decorah, 1929, 90 days.) Height 32, size 41/2. Soft cream with pink edging. Very exquisite flower. Good propagator.

LOYALTY. (Austin, 1928, 95 days.) Height 46, size 4. One of the finest yellows. Tall spike and strong grower, making many stalks from one bulb. Prolific, but not an extra good germinator.

MAGNET. (Crow, 1929.) Said to be an improved Golden Dream. Fairly good propagator-I should say germinator, for the bulblets were quite plentiful.

MAMмOTH WHITE. (United Bulb Co., 1926, 94 days.) Height 43, size 6. Pure white with faint cream in throat. The largest white, and one of the largest of any color. A grand exhibition flower. Flowers closely set on straight spikes. You will like this one. Very good propagator.

MANDARIN. (Crow, 1929, 91 days.) Height 37, size 4. Salmon and orange, wonderful new color. We liked this one very much. The form is excellent and it opens a number of florets at a time. Fairly good germinator.

MAPLESHADE GEM. (Dehnhoff, 1929, 81 days.) Height 38, size 41/2. Fine ruffled salmon which should make an excellent cut flower. It is a strong grower, early and a very good propagator.

MARGARET STEVENS. (Stevens, 1929, 73 days.) Height 36, size 4. A pink quite similar to Giant Nymph but much earlier and not so tall. Makes a beautiful basket flower. Fairly prolific from large bulbs.

MARION KOCH. (Austin, 1928, 105 days.) Height 34, size 41/2. Needlepoint type-very pointed petals. Pure old rose on good spike. Strong grower, several open. Good propagator.

MARY McCONNEL. (Stevens, 1929, 83 days.) Pure deep rose of fine color. Not very large or tall however. Prolific.

MARY LOCKWOOD. (Kinyon, 1928, 77 days.) Height 36, size 4. Color quite similar to Rita Beck. Very much earlier. Slender spike. Prolific.

MARY LOU. (McKibben, 1929, 103 days.) Height 38, size 4. Ruffled soft rose with deeper rose on lower petals. Well formed spike. Nice flower. Very heavy propagator.

MARY VAN. (Kinyon, 1929, 98 days.) Height 36, size 41/2. Pure self colored pink of very fine form. Silver medal winner at Toledo, in commercial seedling class, 1928. Good grower and propagator.

MATILDA ANN. (Diener, 1927, 106 days.) Height 40, size 5. An attractive creamy white of beautiful form. Fine spike and flower. Almost lacinated. Fairly good propagator.

MIBLOOM. (Stevens, 1928, 77 days.) Height 40, size 4. Pure milk white with scarlet blotch on lower petals, apparently reflecting the scarlet on upper side of the flower. Excellent grower and very prolific.

MILADY IMOGENE. (Austin, 1928, 95 days.) Height 36, size 31/2. Soft white prim grandiflora. A most beautiful florists' flower. Nice grower and propagator.

MIMI. (Salbach, 1928, 96 days.) Height 39, size 4. Soft pink with red blotch on lower petals. An attractive flower and good propagator.

MISS CALIFORNIA. (Salbach, 1929, 94 days.) Height 46, size 4. Soft salmon pink of nice form. Prim grandiflora. Prolific.

MISS DES MOINES. (Decorah, 1927, 96 days.) Height 38, size 41/2. A beautiful lavender glad, with cream yellow throat. Fine placement and several open. Seems to be quite a good propagator. 


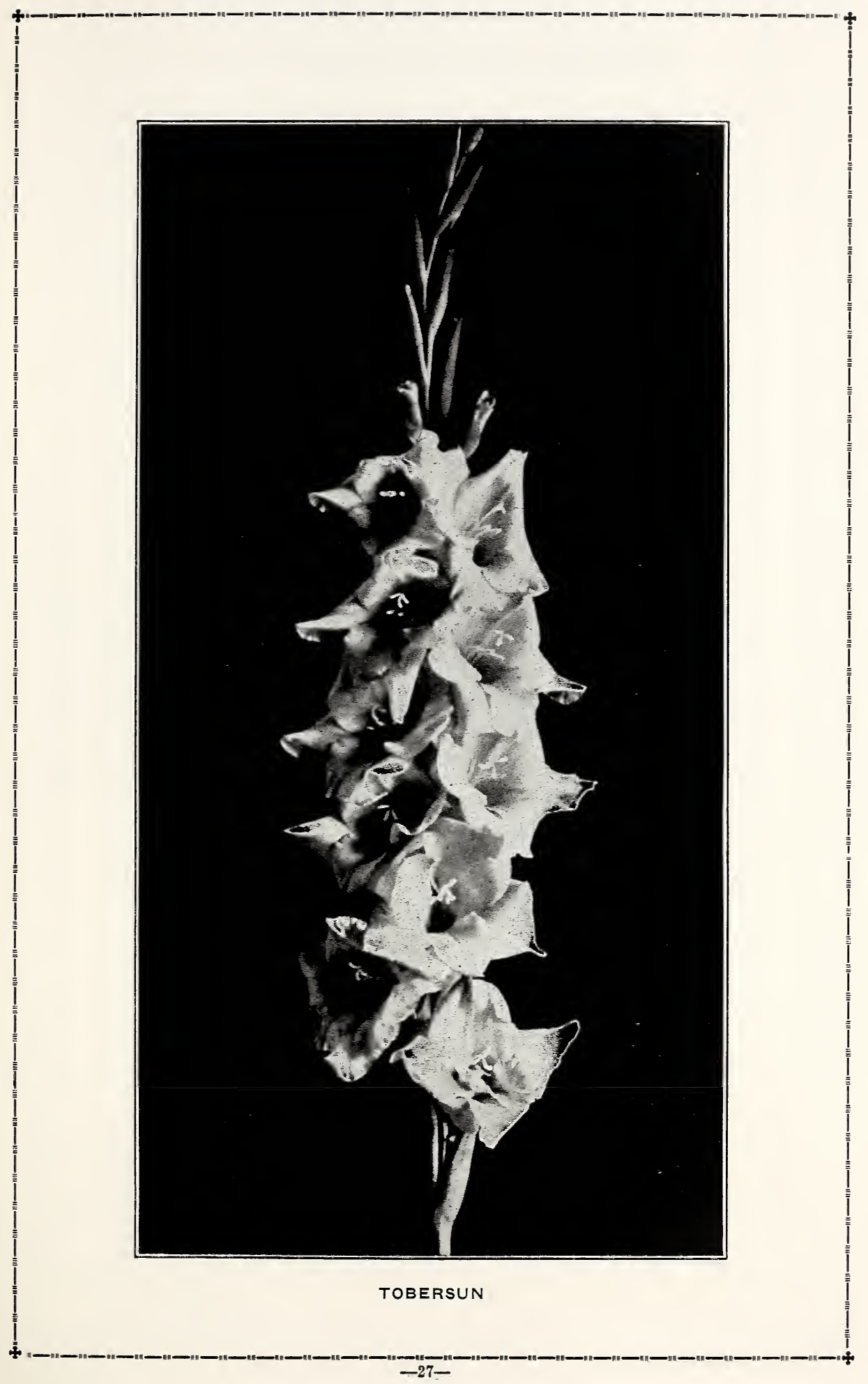




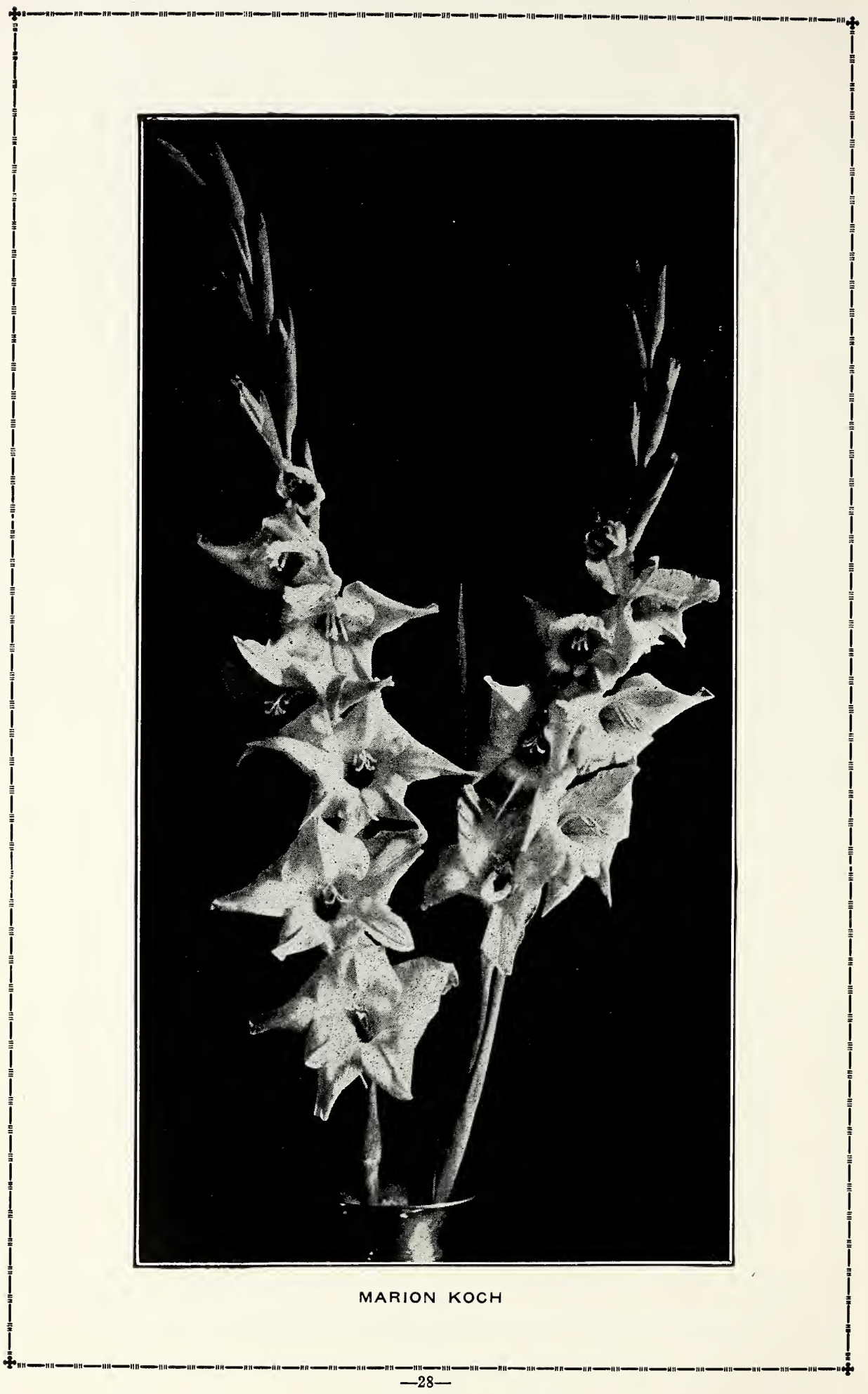


MISS EUGENE DECISAY. (Gage, 1929, 90 days.) Height 39, size 4. Rather attractive orange and apricot, speckled darker. Quite prolific.

MISS NEW YORK. (Hornberger, 1929, 95 days.) Height 41, size 41/2. Soft pink with darker throat. A good new commercial pink which grows well and is a good propagator.

MISS UNIVERSE. (Kunderd, 1929.) A good rose red with deeper blotch. An attractive flower, according to originator's description. Good germinator and very prolific.

MONARCH OF THE GLEN. (Ellis, 1928.) This variety did not come into bloom, because of the early frost. Large fluted salmon with darker blotch. About the strongest grower we have. Poor germinator but makes quite a few bulblets.

MOTHER MACHREE. (Stevens, Gove, 1928, 93 days.) Height 38, size 5. A most beautiful smoky variety. Soft grey, salmon, and yet seems flamed with gold. Truly luminous, and the most exquisite variety in this class. Strong grower and a fair propagator.

MRS. CATHERINE EDWARDS. (Hornberger, 1928, 90 days.) Height 38, size 4. A nice cream white with deeper throat. No markings. Good texture and growth. Fair propagator.

MRS. F. E. BENNETT. (Hunt, 1929, 90 days.) Height 38, size 5. Beautiful clear white with clear purple blotches in throat. Wide open and fine spike. A very good variety. Fair propagator.

MRS. HERBERT HOOVER. (Bill, 1929, 93 days.) Height 43, size 41/2. Unusual shade of mauve lavender with deeper mark in throat. Fine form and spike. We like it very much. Quite prolific.

MRS. LEON ENSIGN. (Dehnhoff, 1929, 95 days.) Height 50, size 5. Clear unusual shade of rose pink. Tremendous grower and tall. Good propagator.

MRS. LEO E. MILLER. (Miller, 1928, 105 days.) Height 36, size 4. One of the most exquisite ruffled glads. It was at its best this season when it was dry. Clear salmon to golden yellow in throat. Heavy texture and very heavily ruffled. Very beautiful. Fairly good propagator.

O. D. BALDWIN. (Salbach, 1929, 90 days.) Height 34, size 41/2. Very good red with rich crimson blotch. Beautiful coloring and very nice florets. Good propagator.

ONECA. (Gelser, 1929, 102 days.) Height 36, size 41/2. Pale lavender with deeper throat. Quite slender spike. Fairly prolific.

ORIFLAME. (Kemp, 1927.) Orange and yellow of good form. Good texture. Prolific and a fine germonator and grower.

ORANGE GOLD. (Kunderd, 1929, 97 days.) Height 33, size 4. Rich orange red throat deeper. Very brilliant. Good grower and prolific.

ORANGE FIRE. (Kunderd, 1929, 83 days.) Height 40, size 31/2. Pure orange vermillion, heavily ruffled. Most brilliant color. Strong grower and prolific.

ORANGE WONDER. (Kemp, 1927, 114 days.) Height 36, size 41/2. Pure rich orange of good spike and form. Good cut flower. Fairly good propagator.

ORIENTAL SILK. (Austin, 1929, 97 days.) Height 34, size 4. A most unusual silky textured bloom of deep rose pink. Good form and nice spike. Good propagator. 
ORINDA. (Salbach, 1929, 79 days.) Height 42, size 3. Soft strawberry pink and orange. Nice early cut flower. Prim grand. Good propagator.

PAISLEY. (Austin, 1929.) Unusual shades of blended pink and gold. We have not bloomed it, but it comes highly recommended. Good propagator.

PAULINE KUNDERD. (Kunderd, 1926, 100 days.) Height 35, size 4. Soft pure rose pink to a white throat. A very fine color. Sometimes this variety is among the most beautiful ever produced. Fair propagator.

PHRANIA. (Russel, 1929, 88 days.) Height 42, size 4. Orchid lavender of tall spike and good form. We liked it. A silver medal winner. Quite prolific.

PINK PREMIER. (Bill, 1929, 88 days.) Height 44, size 4. A nice commercial pink of good form and habits. Good propagator.

POINT TWAIN. (Ellis, 1929, 92 days.) Height 36, size 5. We liked this the best of any of the 1929 Ellis varieties. Soft clear pink of most attractive form. Pointed petals. Several open at a time. A most exquisite variety. Good propagator.

PRIDE OF OREGON. (Damon, 1928, 95 days.) Height 34, size 4. Unusual brilliant pink with many open on the spike. Good placement. Fair propagator.

PRIMATE. (Crow, 1929, 96 days.) Height 44, size 4. A beautiful clear yellow. Has some primulinus blood, but not much hooded. Growth is perfect, the color excellent. Heavy propagator and one of the best commercial yellows in a long time.

PRIDE OF PORTLAND. (Ellis, 1927, 96 days.) Height 38, size 5. Clear begonia rose, of large size. Tall straight spikes. A prize winner in the west. Fairly good grower and propagator.

PURPLE CHALLENGE. (Kunderd, 1928, 110 days.) Fine rich purple of much commercial value. Good grower and propagator.

PURPLE PROGRESS. (Kunderd, 1929.) A new variety of the Baron Hulot color, but larger. A good one.

RAMESSES. (Stevens, 1928, 93 days.) Height 52, size 5 $\frac{1 / 2}{2}$. A grand new purple, one of the finest glads in existence. Grand spike of perfectly placed florets of clear deep rich purple. A shy propagator, so will be high priced for a long time. Fine grower.

RED ALTUS. (McKibben, 1929, 100 days.) Height 40, size 4. A nice commercial red on slender stems. We rather liked it. Good propagator.

RED TORNADO. (Ellis, 1926, 108 days.) Height 40, size 5. A very good red, especially late in the season when it is cold and rainy. Very rich throat blotch. Not an especially strong grower but a good propagator.

RIGOLETTO. (Pety, 1929, 92 days.) Height 36, size 4. Light pink, blotched deep red. A good strong spike, and good grower and propagator.

RIPPLES. (McKibben, 1929, 96 days.) Height 36, size 4. A pink on the order of Mrs. Sisson. Seems to scarcely be as large, but is a better propagator, because the bulblets make greater growth, and are equally plentiful.

RONALD AMUNDSEN. (Decorah, 1929, 96 days.) Height 36, size 4. A red very similar to Finn Malgrem, but different in shade. A fine variety for florists. Good spike and quite prolific. 


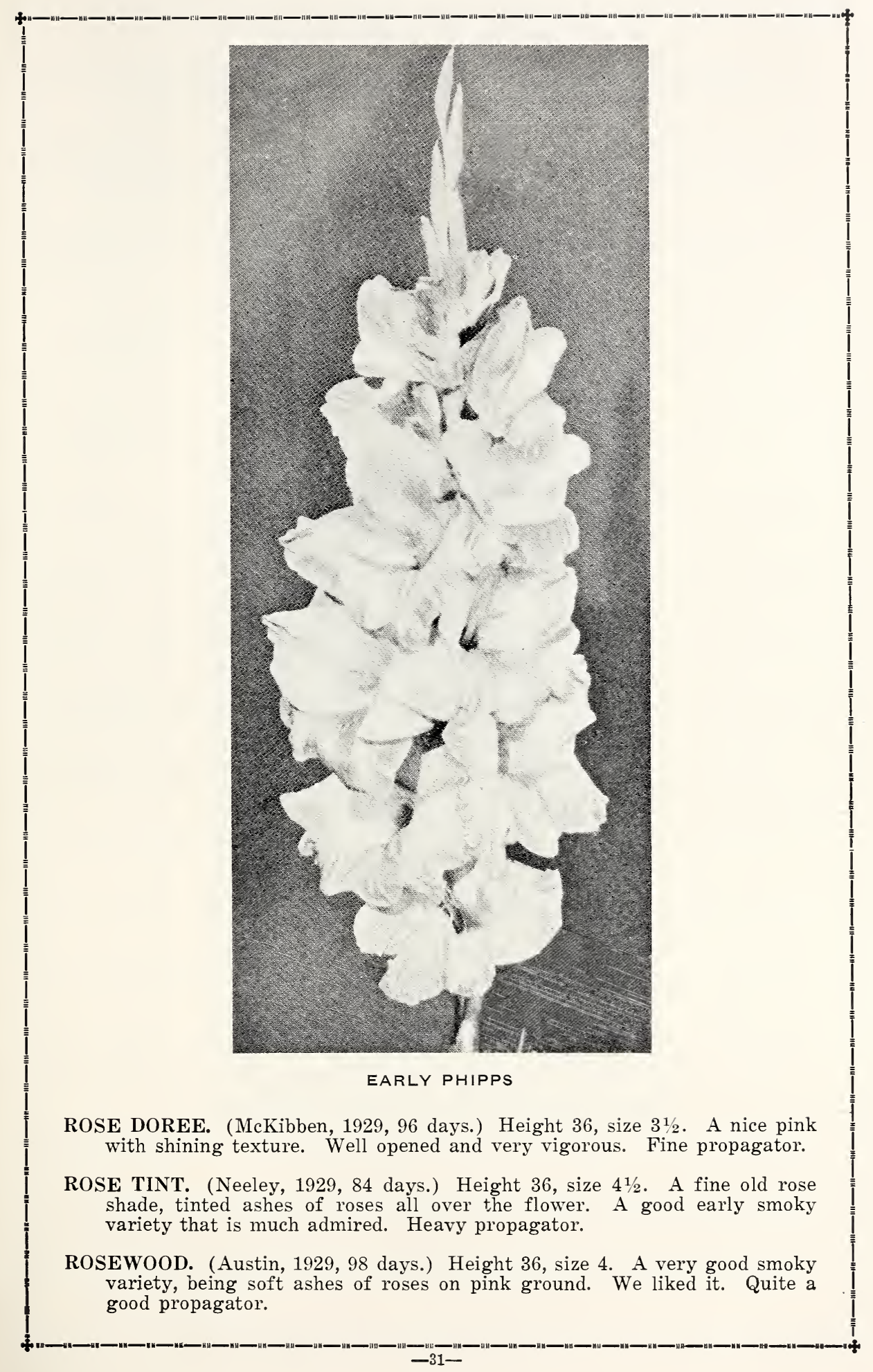


ROYAL LAVENDER. (Schneider, Gove, 1929, 96 days.) Height 40, size 41/2. A rich rose lavender of perfect florists' form and an excellent spike. One of the most admired florists' varieties in years. Fair propagator.

RUFFLED GOLD. (Goodrich, 1927, 84 days.) Height 38, size 5. A fine medium yellow, of very attractive form. Nicely ruffled and a good willowy spike. Should make a good commercial variety. Excellent propagator.

SALBACH'S PINK. (Salbach, 1929, 103 days.) Height 43, size 5. A beautiful clear geranium pink with soft carmine throat markings. Well placed florets on good spike. Strong grower, very reliable and an excellent propagator.

SAN MATEO. (Salbach, 1928, 95 days.) Height 34, size 4. Soft rose pink on the order of Pink Liky, but much larger and better. A good propagator, and we like it.

SENORITA. (Salbach, 1928, 98 days.) Height 35, size 5. A very unusual shade of yellow orange of peculiar formation. Long narrow petals and many florets closely set, open at a time. Looks like a huge chrysanthemum. Good propagator.

SHASTA GOLD. (Gage, 96 days.) Height 39, size 4 . A very good slender yellow which is well liked wherever shown. Fairly good propagator.

SHEBA. (Salbach, 1928, 86 days.) Height 42, size 5. A very tall early pink of good size. Clear color and good form. Fine propagator.

SIGRED STEIN. (Carpenter, 1929, 74 days.) Height 32, size 31/2. A nice cream white florists' flower. Fairly prolific.

SIR THOS. LIPTON. (Salbach, 1929.) Salmon, flaked steel blue. We have not bloomed this one, but it comes highly recommended. Good propagator.

SOLENGE. (Pety, 1929, 94 days.) Height 41, size 41/2. Soft creamy white, tinted pink. Very nice form and an exquisite form. Not always perfectly placed. Good propagator.

SOMERSET. (Crow, 1929, 89 days.) Height 44, size 4. Nice commercial purple of good shape. Good propagator.

SONNY BOY. (Bill, 1929, 94 days.) Height 36, size 31/2. Soft orange and yellow. An attractive flower on nice spike. Fairly prolific.

SULTAN. (Crow, 1929, 91 days.) Height 37, size 5. A grand ruffled dark crimson. This was one of the outstanding varieties we flowered the past season. Fairly good propagator.

SUNSHINE GIRL. (Stevens, 1929, 82 days.) Height 40, size 41/2. Soft salmon with almost clear throat. A beautiful flower of most attractive form and spike. In addition to its earliness, it is a fine easy grower and a very good propagator.

SYLVIA WEST. (Rugowski, 1927, 92 days.) Height 28, size 31/2. Very nice form, and pure white. Fairly good propagator.

THE GRAND GUARDIAN. (Austin, 1929, 91 days.) Height 37, size 4. Soft deep yellow with slight carmine markings in throat. Good propagator.

THE SILVER THREAD. (Austin, 1929, 75 days.) Height 33, size 4. Clear carmine with a silver thread around each of the long narrow petals. A novelty indeed. Good propagator. 
THOS. EDISON. (Kunderd, 1927, 95 days.) Height 38, size 4. Rich clear dark red. One of the most attractive reds. It seems to lack vigor some seasons, but the attractive form is always there. Beautiful. Fairly good propagator.

TOBERSUN. (Austin, 1928, 98 days.) Height 42, size 4. A nice soft yellow with slight carmine markings in throat. We like it very much. Quite a good propagator.

VAN. (Sterens, 1929, 82 days.) Height 38 ; size $3{ }^{1} 2$. Beautiful clear buff with purple mark in the throat. Good grower and propagator.

W. G. WELKER. (Gelser, 1929, 95 days. Height 45, size 5. A beautiful clear begonia rose with deeper blotch. Fine flower on good spike. Not very prolific.

WYOMING. (Gelser, 1929, 81 days.) Height 40, size 4. An unusual lavender with much yellow in center. We liked it.

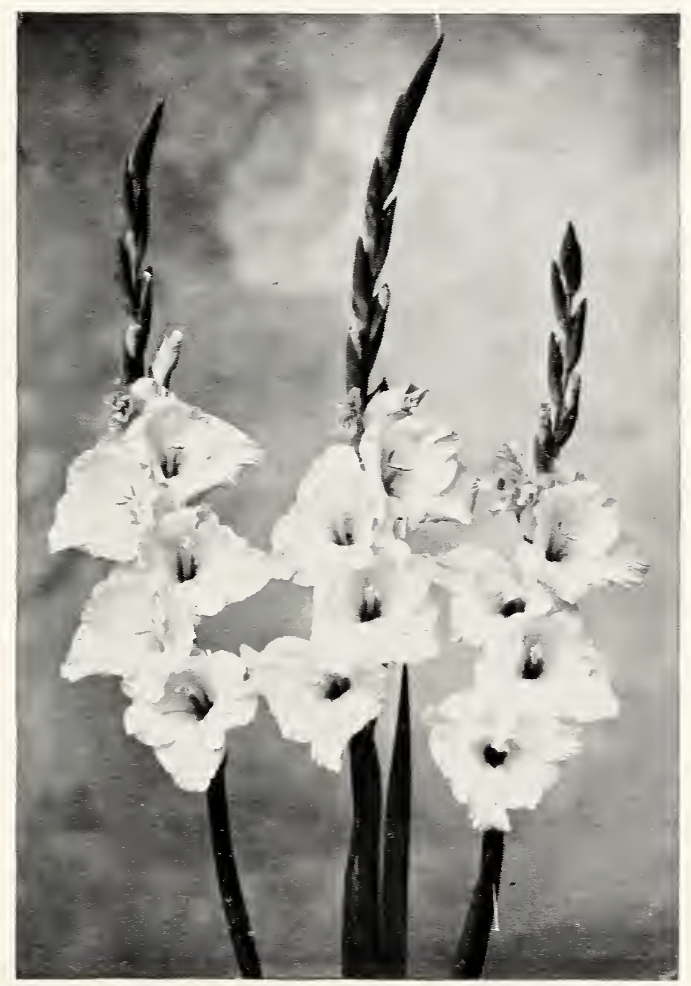

ANNIE LAURIE

Did you have flowers enough last season to keep your home decorated as you wished? Or to give to your friends? Or for the many other purposes that flowers-and above all others-gladsmay be used? 


\section{Primulinus Varieties-}

A distinct type of glads, making a more slender spike than the large flowered varieties, and with florets set farther apart. They are graceful and extremely artistic. One spike alone is not a great sight, but in a basket, decorations, or elsewhere, they are exquisite. Many of the most delicate colors of all glads are found in this strain.

ADA DE POY. (Salbach, 1925, 78 days.) Height 42, size 31/2. Exquisite clear apricot with bronze shadings. Six to eight open. A favorite. Good propagator.

AFLAME. (Hornberger, 1926, 94 days.) Height 48, size 51/2. The largest of the prim grands. Tall spike with many florets open at a time. Begonia rose with backs of petals brighter than the faces. Excellent propagator.

ANNIE LAURIE. (Brown, 1925, 90 days.) Height 35, size 4. Exquisite fresh pink on white ground. Strong straight willowy spike. One of the finest new commercial varieties. Good propagator.

ALAN V. BUNCE. (Bill, 1923, 90 days.) Height 43, size 5. Excellent orange with deeper throat striples. This variety was grand with us the past season. Fairly good propagator.

APRICOT GLOW. (Palmer, 1928, 92 days.) Height 41, size 41ㄹ․ Soft apricot bugg. Clear and exquisite. Almost the best new prim on the market. Color is unbeatable. A much improved Ming Top and an excellent propagator.

BUDDY WORDEN. (Austin, 1927, 83 days.) Height 37, size 21/2. Burnt orange, tinted pink. Blooms over a long period of time. Splendid for bowls and table decorations. Good propagator.

CARA MIA. (Miller, 1926, 87 days.) Height 40, size 4. Soft prim with deeper line on lower petals. Nice form and good spike. Excellent commerial variety. Fine propagator.

CLARA. (Dehnhoff, 1929, 80 days.) Height 36, size 3. Soft violet purple with yellow in throat. One of the best in this color. Good propagator.

COPPERBRONZE. (Kunderd, 1925, 84 days.) Height 38, size 5. Large coppery bronze. Very unusual shade in any type. In good demand. Heavy propagator.

COPPER GOLD. (Kunderd, 1928, 82 days.) Height 40, size 4. Exquisite soft salmon and yellow. One of the finest prims in existence. Good propagator.

EVENING. (Kunderd, 1927, 82 days.) Height 37, size 31/2. Soft pink with yellow in throat. Nice color and fairly good propagator.

FAIRY LANTERN. (Neeley, 1929, 76 days.) Height 37, size 4. An exquisite novelty, violet veined yellow with yellow throat. Florets hang from spikes like Chinese lanterns. Prolific but a poor propagator.

ELSIA. (Estzel, 1925, 90 days.) Height 38, size 31/2. A wide open yellow prim with a greenish cast. Very deep color, darker even than Souvenir. Good propagator.

GLADDIE BOY. (Bill, 1924, 83 days.) Height 44, size 5. Beautiful salmon orange. Large winged florets on tall spikes. We like it very much. Not an excellent propagator, but fair. 
The Lord God planted a garden

In the first white days of the world, And set there an angel warden,

In a garment of light unfurled;

So near to the peace of Heaven,

The hawk might rest with the wren;

For there in the cool of even

God walked with the first of men.

And I dream that his garden closes,

With its shade and its sunflecked sod,

And its lilies and bowers of roses

Were laid by the hand of God.

The kiss of the sun for pardon,

The song of the birds for mirth-

One is nearer God's heart in a garden

Than anywhere else on earth.

-D. F. Gurney. 
GLADSOME. (Suttle, Thacker, 1927, 78 days.) Height 39, size 41/2. Pure yellow with deeper throat. Never shows any other color. One of the best early varieties we have grown. Clear healthy grower. Fine propagator.

GOLDEN AMBER. (Salbach, 1928, 86 days.) Height 47, size 4. Rich deep yellow with copper tint. Strong grower and good propagator.

GOLDEN FRILLS. (Kunderd, 1925, 80 days.) Height 35, size 31/2. Deep rich yellow with a cerise feather in throat. Nicely ruffled. One of the best. Excellent propagator.

GOLDEN VICTOR. (Kunderd, 1928, 77 days.) Height 54, size 3. Richest yellow. Good for so early a variety. Fine for cutting because of height. Prolific.

HONEYDEW. (Decorah, 1928, 92 days.) Height 40, size 3. Soft amber. Unusual form on spike. Nicely lacinated. Heavy propagator.

HOOSIER PEARL. (Kunderd, 1927, 82 days.) Height 32, size 3. Soft yellow and pink, exquisite. Fairly good propagator.

HALO. (Miller, 1926, 76 days.) Height 36, size 3. Bright golden orange. Nice for landscape. Good propagator.

HARBINGER. (Sanford, 1926, 92 days.) Height 38, size 41/2. Burnt orange, fine for landscaping. Good propagator.

IMPROVED TIPLADY. (Salbach, 1928, 82 days.) Height 37, size 4. Similar to Alice Tiplady, but much taller. Good. Heavy propagator.

JAP. (Kunderd, 1927, 84 days.) Height 39, size 4. Soft clear yellow. Softer and larger than Souvenir. Good propagator.

KRELAGE'S FAVORITE. (Krelage, 1925, 88 days. Height 40, size 4. Rich red of unusual shade. One of the best red prims. Prolific.

LENE WONE. (Kunderd, 192 7,81 days.) Height 30, size 3. Rich orange, fine for florists' work. Deeper than Halo. Fairly good propagator.

LA VERNE. (Houdyshel, 1925, 92 days.) Height 42, size 4¹/2. Light yellow, flushed pink. Nice basket flower. Propagates well.

LE CYGNE. (Houdyshel, 1927, 89 days.) Height 34, size 31/2. Pure white of nice form. Good florists' flower. Prolific but not a good propagator.

GOLDEN SNAPDRAGON. (Kunderd, 1927, 82 days.) Height 36, size 3. New attractive type. Yellow and cream. Fairly good propagator.

GOLDEN SWALLOW. (Austin, 1924, 89 days.) Height 34, size 41/2. A very artistic yellow with pointed petals. Splendid form. Good propagator.

MANDARIN. (Decorah, 1929, 72 days.) Height 36, size 31/2. Do not confuse with Crow's Mandarin. A fine early orange prim, with clear yellow throat. Fine propagator.

MISSION BELLS. (Briggs, 1925, 88 days.) Height 35, size 31/2. Heavily hooded orange pink. Quite good. Fairly good propagator.

MISS JOY. (Holmes, 1928, 91 days.) Height 38, size 4. A soft pink, blended to a yellow throat. An excellent new prim of great possibilities as a commercial flower. We liked it. Good propagator.

MRS. CALVIN COOLIDGE. (Kunderd, 1927, 87 days.) Height 36, size 4. Softest salmon with pure yellow throat. One of the finest prims. Good in every way. Excellent propagator. 
MONGOLIA. (Kunderd, 1928, 82 days.) Height 48, size 31/2. Deepest yellow of any. A really fine yellow variety, not much hooded. We considered it among the very finest. Very prolific.

NORA LEE. (Wetzel, 1925, 82 days.) Height 34, size 3. Soft rose pink to a white throat. Very dainty and different. Quite a good propagator.

ORANGF BUTTERFLY. (Salbach, 1928, 92 days.) Height 42, size 4. Beautiful orange and bronze, on fine spike. Fine prim-one of the best. Excellent propagator.

ORANGE DELIGHT. (Kunderd, 1927, 90 days.) Height 34, size 31/2. Another burnt orange, giving a lacinated impression. Nice for work, a strong grower and excellent propagator.

ORANGE SMOKE. (Stevens, 1928, 96 days.) Height 40, size 31/2. A little like Copper Bronze in color but not so large. Nice basket flower. Heavy propagator.

ORANGE QUEEN. (Pfitzer, 1921, 79 days.) Height 38, size 4. Perhaps the most exquisite pale pink prim. Nice spike. No markings. In some combinations it is almost ethereal. Good propagator.

PATRICIA CARTER. (Kunderd, 1926, 86 days.) Height 35, size 31/2. The most exquiiste pale pink prim. Nice spike. No markings. In some combinations it is almost ethereal. Good propagattor.

PEARL O' MINE. (Zimmerman, Sawyer, 1929, 83 days.) Height 35, size 311/2. Soft cream. Beautiful as a basket flower. Fairly good propagator.

QUEEN OF BREMEN. (Zimmer, 1929, 80 days.) Height 36, size 4. Soft amaranth pink, the only prim in this color and very valuable commercially. Heavy prize winner. Very good prospective cut flower. Fine propagator.

RADIANT QUEEN. (Hornberger, 1928, 94 days.) Height 36, size 31ㄹ․ Something like Orange Queen but a richer color. More orange and saffron. Good grower and propagator.

RUBY GEM. (Pety, 1928, 92 days.) Height 32, size 3. Rich ruby red somewhat lacinated. Very dainty and an unusual color. Good propagator.

ROSE MIST. (Fischer, 1924, 90 days.) Height 40, size 4. Rose red called crushed strawberry with buff line around the petals. Tall spike with several well placed florets open at a time. A grand prim, one of the finest and most popular. Fair propagator.

SANTA MARIA. (Briggs, 83 days.) Height 43, size 3. Rich orange. Would be grand in a basket. Prolific.

SHELL PINK. (Kunderd, 1921, 84 days.) Height 35, size 31/2. Soft pink with clear white throat. Nice commercial flower. Prolific, but a poor germinator.

SOUVENIR. (Gravereau, 1921, 79 days.) Height 40, size 31/2. The most popular yellow prim. Rich deep color and fine spikes. Good propagator.

SUNNY SONNY. (Houdyshel, 1926, 86 days.) Height 42, size 31/2. Wide open bronzy pink. Ruffled and strong. Good propagator.

SUNSHINE GLOW. (Neeley, 1929, 82 days.) Richest sparkling scarlet with a pure yellow throat. One of the brightest glads in the garden. Unusual form and heavy substance. Excellent propagator.

SWEETER SEVENTEEN. (Kunderd, 1927, 82 days.) Height 35, size $3^{1 / 2}$. Soft salmon to a yellow throat. Attractive and good propagator. 


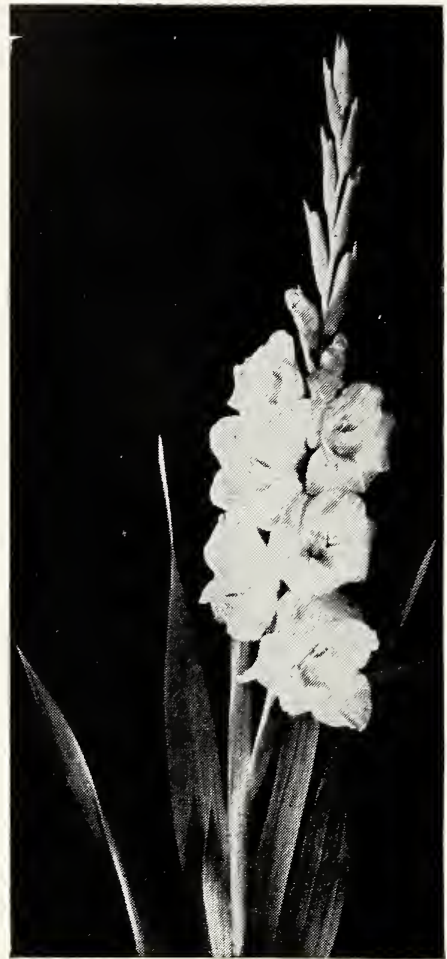

Are you one of those people who have said "I don't care for prims?" If you are-we challenge you to plant enough Golden Frills-Scarlet Bedder-Ada de Poy-or any others of the better class. Dare you try it?

ROYAL LAVENDER

SCARLET BEDDER. (Salbach, 1927, 84 days.) Height 34, size 4. The finest red prim we have found. Pure soft scarlet with no markings. The florists'flower. Good spikes of medium height. Good propagator.

SUNKIST FAIRY. (Pety, 1928, 90 days.) Height 30, size 31/2. Soft orange with deeper throat. Exquisite. Nice for landscaping and making up. Good propagator.

SALMON GLOW. (Hornberger, 1926, 74 days.) Height 35, size 5. Excellent early cut flower. Pure salmon with yellow throat. Much hooded. Heavy Good propagator.

THE EMIR. (Pety, 1928, 97 days.) Height 24, size 3. Dull bronze shaded lighter. Unusual oriental coloring. Attracts much attention. Good propagator.

THE ORCHID. (Sprague, 1926, 82 days.) Height 35, size 41/2. Orchid shape and color. Fine florists' flower. Strong and very prolific.

VIRGINIA LOU. (Kunderd, 1926, 91 days.) Height 38, size 4. Old rose with creamy throat. Very good cut flower. Excellent propagator.

ZONA. (Kunderd, 1927, 79 days.) Height 40, size 4. Soft pink with yellow throat, with carmine blotch. One of the finest of all prims-extremely attractive. We are very fond of it. Heavy propagator. 


\section{The Finer Varieties From Scotland}

A. E. AMOS. (Mair, 1927, 88 days.) Height 42, size 4. White with purple lines and flakes. Propagates well.

APRICOT. (Mair, 87 days.) Height 36, size 4. A very good exhibition flower. Salmon with scarcely any markings. Eight open. A moderate grower however, and while it makes plenty of bulblets, they are not of the best germination.

BERTY SNOW. (Mair, 88 days.) Height 40, size. A wonderful commercial lavender variety. While it may streak under certain conditions, yet the size, form, spike and growing combined with the fact that it is an excellent propagator, make it one of the best of all glads. By all means grow it.

BETTY. (Mair, 1927, 92 days.) Height 40, size 4. Clear pink with white blotch on lower petals. Fine spike and form. Good propagator.

CARRICK. (Mair, 102 days.) Height 45, size 31/2. Smoky rose on tall spike. Must be staked. Prolific and moderate growth from bulblets. A good variety.

CHARM. (Mair). Soft pink and white. Exquisite white, and farily good propagator.

COMRADE. (Mair, 1927, 92 days.) Height 46, size 4. Food spike of slaty salmon. Cream throat. Distinctive. Good propagator.

DAVID AIRDRIE. (Mair, 84 days.) Height 43, size 41/2. Good carmine with cream throat. Well worth while. Prolific and good germinator.

DIGNITY. (Mair, 1927, 91 days.) Height 42, size 4. Soft rose of good form. Nice spike. Fairly good propagator.

DUCHESS OF YORK. (Mair, 98 days.) Height 40, size $4 \frac{1}{2} 2$. Similar to Berty Snow in form, but a clear ashy rose. Excellent. Prolific but not an extra good germinator.

FIELD MARSHALL. (Mair, 1927, 88 days.) Height 36, size 5. Deep smoky red. Much darker than Comrade. A splendid variety in this glad Good propagator.

GLORIOSA. (Mair, 102 days.) Height 40, size 41/2. A rich scarlet red with pure white blotch. Beautiful spike and fine form. Very prolific and a moderate germinator.

GUY MANNERING. (Mair, 1927, 96 days.) Height 38, size 4. Deep violet with white throat. Fair propagator.

JESSIE. (Mair, 1927, 92 days.) Height 38, size 5. Rich pink with pure white throat. Good spike and flower. Good propagator.

KING GEORGE. (Mair, 85 days.) Height 45, size 41\%2. An excellent dark red with cream blotch. Tall perfectly placed florets. Fine substance and grower. Not an extra good germinator.

MARVEL. (Mair, 90 days.) Height 36, size 4. Rose pink with rich golden blotch. Moderate height and form, but most unusual in color. Good propagator.

MRS. CUTHBERTSON. (Mair, 1928, 90 days.) Height 36, size 4. Excellent spike of most attractive form. Heavily ruffled florets of excellent substance. Outstanding and an excellent propagator. 
MRS. GALBRAITH. (Mair, 76 days.) Height 34, size 4. A good early salmon. Several open. Excellent propagator. Good commercial pink.

NELLY. (Mair, 1928, 93 days.) Height 42, size 5. Good flower of delicate rose with crimson in throat. Large spikes of excellent form. Good propagator.

QUEEN MARY. (Mair.) White with cream tint. Beautiful form and many florest open at a time. Seems to be at least a fairly good propagator.

SULTAN. (Mair, 1927, 81 days.) Height 42, size 5. Quite similar to Field Marshall, but much earlier, and more yellow in that. A fine variety and good propagator.

SUNSET. (Mair, 1927, 83 days.) Height 42, size 4. Very good soft salmon color. Placement could be improved upon. Good propagator.

\section{From Continental Europe-}

Many of the finest varieties grown are from this section, and we are pleased to list them herewith.

AIDA. (Pfitzer, 1927, 79 days.) Height 40, size 4. Deep violet with rich blotch in throat. One of the finest in the shade. Very frequently blooms from bulblets and is an excellent propagator.

ALBATROSS. (Pfitzer, 1927, 77 days.) Height 50, size 5. The purity, size and height of this variety is the finest of anything on the market in this color. We still believe it to be the finest white. Strong and an excellent propagator.

AVE MARIA. (Pfitzer, 1928, 96 days.) Height 42, size 41/2. Deep violet blue, with almost crimson blotch. Excellent substance, form and spike. Good propagator.

CAROLUS CLUSIUS. (Velthuys, 1927, 85 days.) Height 40, size 5. One of the finest commercial pinks on the market. Perfect spike and form, and of excellent color. Great grower and propagator. In big demand already.

CORYPHEE. (Pfitzer 1927, 95 days.) Height 46, size 51/2. Purest pink blended to a white throat. Perfect form and excellent substance. Good grower and propagator. One of the most beautiful glads in existence.

EMMA. (Velthuys, 1927, 91 days.) Height 37, size 31/2. Large rose pink with heavy dark blotches on lower petal. Fair propagator.

EMILE AUBRUN. (Lemoine, 92 days.) Height 46, size 5. Huge smoky bronze with cherry center. Round flowers well placed. Very prolific and a fair germinator.

FAIRY DIAMOND. (Alkemade, 1926, 88 days.) Height 38, size 41/2. An excellent rich red, large well placed florets. One of the best early reds. Good propagator.

FLORENCE L. BARCLAY. (Alkemade, 1926, 79 days.) Height 36, size 4. Soft pink with clear throat. Beautiful form and texture. Fair propagator.

GERTRUDE PFITZER. (Pfitzer 1927, 91 days.) Height 43, size 4. A fine new blue-one of the best for commercial use. Strong grower. Quite a good propagator. 
HEAVENLY BLUE. (Ffitzer 1926, 92 days.) Height 38, size 4. Almost the finest blue color. Graceful spike and perfect placement, well named. Fades out when cut, to almost white. Fairly good propagator.

HELIOSA. (Pfitzer, 79 days.) Height 36, size 41/2. A most exquisite clear deep yellow. Wonderful form. Spikes sometimes are bent, but the florets are so fine that it is very worth while. Does not propagate at all well.

KRIMHILDE. (Pfitzer, 1927, 81 days.) Height 40, size 5. Large lilac pink. Heavy spike with many well arranged florets. Fine show flower and good for commercial use as well. Excellent propagator.

INVINCIBLE. (Alkemade, 1927, 96 days.) eHight 36, size 4. Good soft rose pink with darker throat. Fair propagator.

JOHNKEER VAN TETS. (Pfitzer, 1928, 84 days.) Pure white of beautiful and perfect form. Fine spike. Prolific and a fairly good germinator.

LA GAIETE. (Velthuys, 1926, 92 days.) Height 37, size 41/2. Light pink with darker throat of richest color. Fair substance, and an excellent cut flower. Good propagator.

MOROCCO. (Pfitzer 1928, 90 days.) Height 35, size 31/2. Very dark red. One of the good black varieties. Excellent propagator.

MRS. ANNA PFITZER. (Pfitzer 1928, 90 days.) Height 42, size 5. Rich creamy white. Perfect form and spike. Grand exhibition flower. Prolific and a good germinator.

MRS. VAN KONYUENBURG. (Pfitzer, 1925, 95 days.) Height 40, size 4. One of the best commercial blues. Form could stand improvement but growth is good and the color excellent. Good propagator.

NON PlUS ULTRA. (96 days.) Height 35, size 4. A good white from Holland. Cream throat. Good propagator.

PAUL PFITZER. (Pfitzer, 1925, 91 days.) Height 39, size 41/2. Clear reddish purple of very attractive form. Excellent commercial variety. Well ruffled. Strong and farily good propagator.

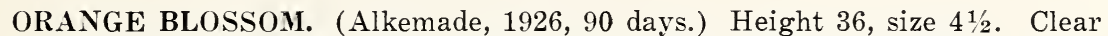
orange with deeper center. Fine round florets. Fair propagator.

ORANION. (Alkemade, 1927, 75 days.) Height 33, size 41/2. An excellent burnt orange, not tall but very attractive Iorm with pointed petals. Valuable on account of its earliness. Quite a good propagator.

OTHELLO. (Pfitzer, 1924, 86 days.) Height 38, size 5. Violet blue. Different in color from any other. Good grower and propagator.

PERFECTA. (Alkemade, 1926, 108 days.) Height 40, size 41/2. Exquisite white. Several florets perfectly placed on an excellent spike, are very nicely frilled. A very fine propagator. One of the best whites we have grown.

PERLE DES JARDINS. (Alkemade, 1927, 85 days.) Height 32, size 31/2. Not a large flower, but the color is very fresh and dainty. Fairly strong grower and a moderate propagator.

PFITZER'S TRIUMPH. (Pfitzer, 1925, 90 days.) Height 40, size 51/2. Perhaps the most popular glad today. The size and substance make it a grand flower for either exhibition or commercial use. While it is not satisfactory in the garden, but for any other purpose, it is the most sensational thing introduced in years. Fine grower and an excellent propagator. Our bulblets made many number two bulbs. 
PHAENOMEN. (Pfitzer, 1924, 90 days.) Height 36, size 31/2. Soft pink and yellow. Not large but fine coloring. Prolific, but bulblets do not germinate well with us.

PRINCESS JULIANA. (87 days.) Height 37, size 4. Very clear salmon orange. Nice flower and spike. Fairly good propagator.

PROF. KEESOM. (Drelage, 1927, 73 days.) Height 38, size 4. Clear reddish salmon with large dark blotch. Good early cut flower. Prolific and fairly good germinator.

PROF. SLOGTERAN. (Alkemade, 1927, 90 days.) Height 36, size 41/2. One of the best. Clear pink of fine form and spike. Excellent substance. Very good propagator.

PUREST OF ALL. (Pfitzer, 1924, 85 days.) Height 28, size 5. Height 28, size 5. Pure white. Except for the short spike, and excellent variety. One of the good early white. Good propagator.

PURPUREA. (Velthuys, 1926, 76 days.) Height 35, size 4. Very good commercial purple. Early and prolific bloomer. Excellent propagator.

ROODKAPJE. (Pfitzer, 1923, 92 days.) Height 36, size 41/2. Good red with very dark throat. Striking. Fairly good propagator.

ROI ALBERT. (Lemoine, 1926, 97 days.) Height 37, size 4. Coppery salmon with darker throat. One of the choicest varieties among the smoky ones. Fair propagator.

ROSA BELLE. (Pfitzer, 1926, 100 days.) Height 45, size 5. Purest rose pink shading to a clear throat. One of the most beautiful of all pinks. Perfect form and spike. Unfortunately and very poor propagator.

RUDOLPH VALENTINO. (Velthuys, 1927, 8 days.) Height 38, size 31/2. Good pink of excellent substance. Nice form. Very good propagator.

SALMON WONDER. (Alkemade, 1927, 86 days.) Height 30, size 4. Nice salmon with wide open florets. Several open. Fair propagator.

STUTTGARDA. (Pfitzer 192888 days.) Height 35, size 41/2. Orange red of wide open form. Fades in the sun. Fair propagator.

SWEETHEART. (81 days.) Height 35, size 4. Soft rose to a lighter throat. Good spike. Excellent for early cut flower. Good propagator.

TROUBADOUR. (Pfitzer, 1927, 85 days.) Height 36, size 5. Richest reddish purple. One of the best in this color. Large number open. Fine propagator.

WODAN. (Pfitzer, 1928, 86 days.) Height 36, size 4. Rich violet blue. Good form and excellent substance. Clear color and wide open. Good propagator.

TRUDAL GROTZ. (Pfitzer, 1924, 83 days.) Height 36, size 51/2. Huge rose pink with deep blotch. Heavy substance, strong grower. Fine grower and very good propagator.

YELLOW PERFECTION. (Pfitzer 1928, 88 days.) Height 38, size 41/2. Pure soft yellow with many florets open at a time. Excellent propagator.

YVONNE. (Velthuys, 1926, 82 days.) Height 44, size 5. A wonderful new commercial blush white, with small rose blotches. Tall slender spike carrying many well placed florets. Rich sparkling texture. Early and a very good grower. Grand cut flower. Excellent propagator. 


\section{Some Outstanding Australian and New Zealand Varieties}

AMETHYST. (Symans, 1927, 92 days.) Height 39, size 41/2. Excellent lilac rose. One of the finest lavender, comparable in some ways with Minuet. Good propagator.

AUTAHI. (Doney, 94 days.) Height 38, size 4. Unusual color, orange salmon ground heavily striped deeper giving a smoky appearance. Several open on fine spike. Very good propagator.

AVERILL. (Errey, 86 days.) Height 38, size 4. A good salmon with cream throat. Sometimes flakes. Excellent spike with very good placement. Fairly good propagator.

BETTY LINDEN. (94 days.) Height 41, size 31/2. An attractive shade of rose pink. Several open florets on tall spike. Good texture and a fair propagator.

CANBERRA. (Errey, 1927, 98 days.) Height 42, size 4. Pure yellow, very clear and bright. Tall heavy spike. If the flowers were a little larger for the heavy spike, it would be one of the really great yellows. In spite of this, it is good. Fairly good propagator.

CHANCELLOR. (Errey, 98 days.) Height 40, size 41/2. Good crimson with cream throat. Prolific but a poor germinator.

DAINTINESS. (Errey, 1925, 77 days.) Height 36, size 31/2. Soft lilac with large dark blotch. An improvement on any of our old domestic blues. Bulblet production fair, germination fair, growth excellent.

ENSIGN. (Errey, 92 days.) Height 43, size 5. Bright scarlet red with white blotches. Large round flowers. Good grower and very good propagator.

GERTRUDE ERREY. (Errey, 88 days.) Height 36, size 4. Soft shell pink with shading to white center with deeper markings. Beautiful florists variety. Good propagator.

HINEMOA. (Doney, 90 days.) Height 40, size 5. A grand gladiolus. Huge deep rose flaked darker, with cream blotchses on lower petals. Good bulblet producer, but poor germinator. Withdrawn this season to increase stock.

IREMEL. (Errey, 96 days.) Height 38, size 41/2. Bright crimson. Large florets closely set. Prolific, but poor germinator.

J. W. CRAIG. (Bruce, 98 days.) Height 38, size 41/2. Good deep pink. Tall and well placed florets. Good propagator.

MARMORA. (Errey, 1927, 92 days.) Height 48, size 5. The greatest exhibition glad from Australia, and perhaps from anywhere. Huge florets perfectly placed, with as many as eight to twelve open at a time. Rich smoky lavender with deeper blotch. A glorious variety. Strong grower. Tremendously prolific, and a fair germinator.

MELISSA. (Errey, 1927, 85 days.) Height 36, size 4. Soft creamy yellow, flecked pink. Clear throat. Nice commercial variety. Fairly good propagator. 
MOLLIE DOUGLAS. (Douglas, 99 days.) Height 41, size 5. Clear bronzey rose with deeper blotch in throat. Resembles Emile Auburn. Strong grower and excellent propagator.

MRS. S. A. ERRY. (Errey, 1927, 85 days.) Height 44, size 5. A grand exhibition variety. Orange salmon with deeper blotch. Perfect placement and spike. Excellent substance. Color fades in the sun. One of the finest in spite of this. Quite prolific and a good germinator.

MRS. T. ATTRAY. (Rattray, 107 days.) Height 36, size 4. Rose pink with many florets open at a time. One of the most popular exhibition varieties in Australia. Good grower but very poor propagator.

NIMROD. (Errey, 86 days.) Height 42, size 41/2. Good dark variety on fine slender stem. Well placed. Fairly good propagator.

OLIVAR. (Errey, 1926, 76 days.) Height 34, size 4. Unusual shade of violet blue. Excellent grower but sometimes crooks badly. Fine propagator. very large bulblets.

SENTINAL. (Errey, 97 days.) Height 41, size 4. Fine clear salmon, a good cut flower. Fine propagator.

TITAN. (Errey, 84 days.) Height 37, size 5. Very large salmon with purple mark in throat. Crooks at time. Fairly good propagator.

VICTOR. (Errey, 96 days.) Height 41, size 5. Pure bright scarlet with clear white blotches in throat. Sparkling color always admired. Fairly good propagator.

\section{Free Bulb Offers for Memberships:}

The American Gladiolus Society is doing a great work in increasing the popularity of the gladiolus. The Review, published monthly, is worth more than the membership price, which is $\$ 2.00$ per year.

The Michigan Gladiolus Society is doing for Michigan and other states, a great amount of practical experimentation with fertilizers, etc. These results are free to members, through the quarterly bulletins sent out. The State show is among the greatest in the country. Membership is only $\$ 1.50$.

FREE: Your choice of any bulb or bulbs to value of one dollar for each membership sent in to above societies.

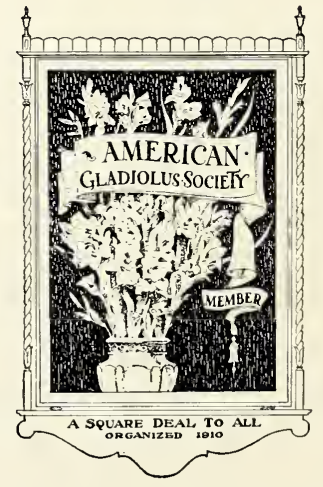

CADILLAC PRINTING CO.. CADILLAC, MICH. 


\section{Against That Day}

The sun is on my path, the way is clear-

Yet I grasp Faith, and hold Faith very near Against that day when black abyss may yawn And Faith be found the one support My trembling feet may rest upon.

There's laughter on my lips and joy is mine, Yet will I guard Faith's flame and mark it shine Against that day when Sorrow is my name And my bowed soul stirs blindly forth To warm it at that flame.

Anxious I work to build my fortress wall Of staunch and sturdy Faith that will not fall Before assault of doubt and canting strifeSo, sheltered there, in sweet content, My soul may save its life.

The sun is on my path, my sky is blue, And Faith seems very strong, and sure, and true;

But I must be assured that Faith will stay When dusk creeps on and I behold

A long, long night that bars the way.

-Jeannette Arnett Leeper. 
